\title{
Critical race and feminist standpoint theories in physics education research: A historical review and potential applications
}

\author{
Miguel Rodriguez $\odot,{ }^{1}$ Ramón Barthelemy, ${ }^{1}$ and Melinda McCormick $\odot^{2}$ \\ ${ }^{1}$ Department of Physics and Astronomy, University of Utah, Salt Lake City, Utah 84112, USA \\ ${ }^{2}$ School of Social Work, Western Michigan University, Kalamazoo, Michigan 49008, USA
}

(Received 1 June 2021; accepted 23 December 2021; published 25 February 2022)

\begin{abstract}
More progress is needed to achieve equity in racial and gender representation in the push to diversify the physical sciences. In order to continue moving towards representation and equity, there is a need for more analytic tools that can help us understand where we are and how we got here. This may also enable meaningful systemic change. In this article, we will review two theoretical frameworks: critical race theory (CRT) and feminist standpoint theory (FST). This paper will guide the reader through the historical context in which each theory was formed, present core tenets and major ideas of each theory, along with external critiques to each theory and where they stand today. This will help readers to further understand CRT and FST, what their role is in education, and how they may be used in physics education research. Simultaneously, this article will serve to broaden perspectives of fundamental societal problems such as racism and sexism.
\end{abstract}

DOI: 10.1103/PhysRevPhysEducRes.18.013101

\section{INTRODUCTION}

Physics education research (PER) as a field is growing, with closer examinations being done on the field [1-6]; part of this growth includes a push to conduct research that is more inclusive of gender, race, and LGBT issues [2,7-24]. In addition to this work, it is important to consider how we approach PER and investigate different options for theoretical framing when studying the persistent pattern of low representation and marginalization of underserved groups in physics.

In physics, women comprise only $20 \%$ of the field at nearly every level, including bachelor degrees, doctoral degrees, and faculty position [25]. Among U.S. citizen recipients, People of Color $^{1}$ in physics earn $23 \%$ of bachelor degrees [26] and 16\% of doctoral degrees [27], while only $6.5 \%$ of all physics faculty are non-white ${ }^{2}$ and non-Asian people [28]. When accounting for international students, which make up the majority of physics doctoral programs, only $1 \%$ of African Americans, $2 \%$ of Hispanic Americans, and less that $1 \%$ of other non-Asian U.S.

\footnotetext{
${ }^{1}$ Words associated with racial identity will be capitalized throughout this article.

${ }^{2}$ The authors decided to lowercase white throughout this article, as recommended by the Associated Press and other critical studies scholars.

Published by the American Physical Society under the terms of the Creative Commons Attribution 4.0 International license. Further distribution of this work must maintain attribution to the author(s) and the published article's title, journal citation, and DOI.
}

citizens of color earn physics doctorates [27]. When considering the intersection of race and gender, Women of Color are even less represented, with Black and Hispanic women earning only $11 \%$ of bachelor and $8 \%$ of doctoral degrees in physics, while making up $6 \%$ of physics faculty at universities with physics PhDs [25]. Unfortunately, their underrepresentation may not just be about access and opportunity, but may also be rooted in structural and cultural barriers that continue to persist in academia and U.S. society overall.

In the broader societal context, the racial disparities in U.S. society remain clear. Racial gaps are evident in wealth [29], educational access [30], healthcare [31], and law enforcement [32] among other inequities in U.S. society. The wealth gap between white and African-American families has grown from $\$ 85000$ in 1984 to $\$ 236500$ in 2009 with an upwards trend continuing ${ }^{3}$ [29]. Non-Asian People of Color have higher rates of poverty [33], the worst being for Native Americans [34]. In education, $40 \%$ of Black and Hispanic students attend high poverty public schools compared to only $6 \%$ of white students [35]. The Covid-19 pandemic has made racial disparities more visible as well. According to the CDC, Black and Hispanic people are 3 times more likely to be hospitalized and twice as likely to die from COVID-19 than white Americans [36]. The pandemic also led to a sharp rise in hate crimes against Asian Americans [37]. In the criminal justice system, Black people are much more likely to be incarcerated than whites. According to the Federal Bureau of Prisons, in 2018,

${ }^{3}$ This increase is more than inflation from 1984 to 2009. 
2272 per 100000 Black male residents are in prison while only 392 per 100000 white male residents are prisoners, meaning Black males are almost six times more likely to go to prison. Shockingly, one of three African-American males have a felony, which effectively serves to eliminate their rights as U.S. citizens [38]. In everyday life, as many as 50\%-75\% of Black, Hispanic, and Asian respondents to a national survey done by the Pew Research Center, reported facing discrimination at some point in their lives, further highlighting the perseverance of discrimination in U.S. society [39]. These are just some of the many examples of racially systemic barriers many People of Color may face.

Although some progress has been made towards gender equality, women continue to face discrimination in the workplace [40], underrepresentation in science, technology, engineering, and mathematics (STEM) fields [41], and are more likely to be victims of sexual assault and harassment [42]. In the workplace, women face discrimination in employment for "masculine" jobs like STEM faculty positions [43] and face a salary gap [44] that increases even more for mothers [45]. Girls overwhelmingly tend to be seen as "inferior" in math than boys by their elementary school teachers, even when having the same scores on math tests and behavioral records [46]. Even though women complete more university degrees than men at every level, women continue to be underrepresented at elite schools [47] and as university faculty members [48]. Violent crimes are also much more likely to happen to women. A report in 2010 found that 1 in 5 women experience sexual assault in their lifetime compared to 1 in 71 men [49]. Sexual harassment continues to plague society, particularly academic workplaces. The rate of sexual harassment of $58 \%$ in the academic workplace is second only to the military's sexual harassment rate of 69\% [50].

People who have more than one oppressed identity often must deal with multiple types of discrimination. For example, Women of Color have to deal with both gender and racial disparities making them more vulnerable to discrimination [51]. There is a larger wage gap for Women of Color than for Men of Color or white women. For every dollar that a white non-Hispanic man earns, Black women earn 63 cents, Latin women earn 55 cents, Native American women earn 60 cents, and Asian women earn as little as 50 cents to as much as 90 cents, depending on their specific cultural background [52]. In general, Women of Color advance to fewer leadership positions [53] and are disproportionately represented in essential low wage jobs [54].

In physics, gender discrimination and racial disparities continue to exist at every level, from undergraduate to postdoctoral [12]. As many as three in four undergraduate women in physics have experienced some type of gender discrimination $[55,56]$. The racial disparities are also clear; for example, a recent survey found that African American and other non-white physics students may have a lower sense of belonging, be more vulnerable to isolation, face more discrimination, and have less affirmation of their abilities by their instructors [57]. These gender and racial disparities continue to persist beyond the student level, also existing at the professional level. For example, a national study found that Black scientists are $10 \%$ less likely to be awarded NIH research funding than their white counterparts, even when controlling for educational background, previous research awards, and publication records [58]. Women have also been found to be underrepresented in the peer review process in many fields, including physics [59]. In astronomy, a field often directly tied to physics, women are less likely to be cited than men [60]. These are just a few examples of the structural and cultural barriers women and People of Color continue to face in physics and academia overall. Issues of racism and sexism are prevalent in U.S. society and the education system at large, well beyond the distinct fields of physics and astronomy.

While there is some work being done to bring justice to these issues in physics, there is also a need for analytic tools to assess where the field is so that we can begin to move toward change and address these systemic inequities. Simply understanding the problem does not suffice; there is a need for theoretical frameworks that can lead to structural and policy changes which may enhance the experiences of underrepresented groups in physics. This paper supports two theoretical frameworks that could be used to improve equity and bring social justice into PER: critical race theory and feminist standpoint theory. These frameworks may be useful in supporting PER and broader STEM education research that is critical of the systems that cause oppression; these critiques can then be used to actively work to rebuild those systems.

Critical race theory has deep roots in legal studies and was created for understanding and transforming the relationship between race, racism, and power [61]. CRT focuses on addressing racism at the systemic level and was formed as a direct result of the civil rights movement and events thereafter. Because of its success in legal studies, it has been adapted into other fields such as education [62], health care [63], and sociology [64]. There are four main tenets of CRT (outlined later in this article), they are (1) racism is ordinary; (2) civil rights only advance when they align with the interest of the elites; (3) race is socially constructed from products of social relations; and (4) unique voices of color must be heard to understand racism [65]. These four tenets are not exhaustive of all the ideas behind CRT, but they are universal across different branches of CRT. CRT challenges liberalist ideas such as meritocracy, race neutrality, and colorblindness. CRT also discusses how topics such as racial differentialization, white privilege, majoritarian stories, and U.S. property rights relate to racism and education.

There are two broad types of CRT scholarship that focus on different aspects of racism [65]: discourse views and 
materialist views. The discourse view is that racism and discrimination are matters of thoughts and ideologies engrained in society [66]. This includes media, language, and other social teachings that influence people's thoughts. From this view, to change racism, those ideologies must be challenged and changed within the social fabric of society. On the other hand, the materialist view is that racism exists as a method for a society to allocate privilege and status [67]. In this view, racism works to create a racial hierarchy that determines who will get the best jobs, go to the best schools, and be awarded higher levels of social status. Changing this system of resource allocation would require changing the economic system (e.g., entrenched poverty among Black and Hispanic families compared to white families) and social situations (e.g., prison and justice system) of underrepresented groups. This paper takes the middle ground, that both views are needed to reduce or eradicate racism (if such a thing is possible). More specifically, this paper will focus on further exploring CRT in PER and STEM education research. All these ideas will first be expanded upon in the literature review with a following discussion on how to apply these ideas further in PER and, consequently, other STEM education research disciplines.

In addition to CRT, this paper will explore feminist standpoint theory. FST is also discussed as standpoint theory (SPT) when considering issues broader than gender; both terms will be used throughout this article. SPT theory evolved from Marxist philosophy that sought to create knowledge and social understanding from the perspective of the oppressed [68]. It was taken up by feminist philosophers and researchers to consider how understanding can be produced from the perspective of women's lives without comparisons to, or opinions of, men. In this way it has been employed as both a framework to do research but also an epistemology to understand how knowledge is created while also questioning its validity. This article will explore FST as both a theoretical framework and epistemology.
As an epistemology, SPT is guided by the idea that knowledge is socially situated in the lived experiences of individuals, who collectively can give voice to their own experiences and the systems that govern them. With this in mind, epistemic privilege is given to the oppressed because they can see the system more clearly as they have no stake in its perpetuation. SPT, however, can also be employed as a theoretical framework in conducting research. From this approach, SPT asks crucial questions about how knowledge is being produced, by whom, and for whose benefit. SPT is one method for exploring the experiences of the oppressed from their perspectives to understand what can be done to better their lives.

Overt racism and sexism are prevalent in U.S. society, and this includes in STEM, STEM education, and PER. While some progress towards these issues have been achieved, many problems continue to persist. We believe that the use of CRT and FST is needed to further understand these forms of oppression and tie them to larger issues in U.S. society.

\section{LITERATURE REVIEW}

Since this article is meant to inform readers on CRT and FST, we start with a background of these theories. For each theoretical framework we will provide a brief historical overview and introduce key concepts. Then we will further explore each theoretical framework and provide references for readers who want to learn more. Critiques for both theories will then be presented and discussed. Lastly, we will briefly discuss intersectionality, since this theoretical framework is central to CRT and FST, in addition to being its own unique framework that stands as an equal to CRT and FST. Before moving on, we provide a list of definitions for common terms throughout this article in Table I; please note that these definitions only serve as a starting point and that we will expand on some of them later.

TABLE I. Common terms and basic definitions taken from the Webster-Merriam dictionary. We will expand on some of them further in the article.

\begin{tabular}{ll}
\hline \hline Term & $\begin{array}{c}\text { Any one of the groups that humans are often divided into based on physical traits regarded as common among } \\
\text { people of shared ancestry. } \\
\text { Race }\end{array}$ \\
$\begin{array}{l}\text { A belief that race is a fundamental determinant of human traits and capacities and that racial differences } \\
\text { produce an inherent superiority of a particular race. }\end{array}$ \\
The quality or state of being equal: the quality or state of having the same rights, social status, etc. \\
$\begin{array}{l}\text { Equality } \\
\text { Taity }\end{array}$ \\
$\begin{array}{l}\text { Ficroaggression or justice in the way people are treated. } \\
\text { A comment or action that subtly and often unconsciously or unintentionally expresses a prejudiced attitude } \\
\text { toward a member of a marginalized group or racial minority. }\end{array}$ \\
\hline \hline
\end{tabular}




\section{A. Critical race theory}

Critical race theory was formed through collaborations between legal scholars of color in response to supreme court decisions that negatively impacted efforts towards social justice and racial equity [69]. CRT has provided legal experts with a tool to successfully defend cases where race may have played a major role [70]. Since its official theoretical formation in the early 1990s, CRT has expanded into other disciplines such as social science [71] and education [62], in order to bring awareness and social justice to the issues of racial inequality to other domains [72]. We will provide some historical reasons why scholars developed CRT and how those ideas were constructed. Once a historical foundation is made, we will go into the core tenets and themes of CRT. Then we will review the foundations of CRT in education. Next, we will present common criticism raised against CRT and offer counternarratives to these critiques. Finally, we will highlight how CRT is currently being challenged.

\section{Historical context}

The history of race in the U.S. is complex and beyond the scope of this article, however it is entangled with the issues of racism in academia and America at large. The modern definition of race began to appear in the 18th century to identify groups of people according to similar physical characteristics [73]. As a result of the success of European colonialism, the idea that white people were superior to non-white people became accepted worldwide over the following centuries [74]. Race was used to morally justify the enslavement of Black people, the abuse of Native Americans, and the countless atrocities committed to them and other non-white people around the world. After the emancipation proclamation a reconstruction period of set in, where the federal government protected freed enslaved people. However, due to changing political tensions, this period only lasted twelve years, officially ending when President Hayes withdrew the federal troops protecting formerly enslaved people in the south in 1877. Southern states, and later some northern ones, began creating white over color systems backed by law and order, to limit voting, housing, and services of non-white people. The Supreme Court upheld these laws as constitutional, including segregation in the Plessy v. Ferguson case in 1896. This part of U.S. history is known as the Jim Crow era and lasted until 1965, when the Voting Rights Act of 1965 was passed [75]. During this period, many violent atrocities also took place against non-white communities, such as the Atlanta massacre in 1906 and the Tulsa Race massacre in 1921, among others.

Significant changes that helped foster better racial equity emerged from the growing social movements in the U.S. at this time. The Brown vs Board of Education ruling in 1954, declaring racial segregation in schools unconstitutional
[76], ushered in a 15-year period of measures directed towards dissembling racism and oppression, including the Civil Rights Act of 1964. Unfortunately, Richard Nixon's four justice appointees to the Supreme Court were less attuned to the concerns of People of Color generally, and Black Americans specifically; as such, the more conservative Supreme Court of the 1970s and 1980s rolled back some of the progress made from the two decades prior. In the 1976 Supreme Court case Washington v. Davis, the court ruled laws that have racial discriminatory effects, but were not "purposely" adopted to advance discrimination, as constitutional [77]. In other words, laws that maintain or generate inequality and underrepresentation are not legally discriminatory if there is no explicit intent. This decision also implied that neutrality could exist, where people could legally take actions that are unintentionally discriminatory, leading to more difficulty in proving discrimination in a court of law. Another example is the 1978 Supreme Court case Regents of the University of California v. Bakke which declared university racial quotas, which preserve spots for racially underrepresented candidates with "lower qualifications," as unconstitutional [78]. This ruling made it unconstitutional for universities to use racial quotas which had been restored by the Civil Rights Act of 1964 for the purpose of increasing representation and diversity.

These, along with other Supreme Court case rulings in the 1970s and 1980s, sparked counterresponses from legal scholars of color that eventually led to critical race theory [79]. After the 1976 Supreme Court decision on discrimination, Freeman wrote an article on the distinct view of discrimination between a victim's perspective in contrast to perpetrator's perspective. For victims, "racial discrimination describes the actual social existence as a member of a perpetual underclass" (pp. 1052-1053) [80]. From their perspective, the elimination of racial discrimination would mean significant changes. The courts, however, held the perpetrator's perspective in legally choosing what classifies as discrimination; at the time all of the Supreme Court justices were white men. This presents the importance of listening to the voices of the oppressed, because their lived experiences provide truths of which those in the dominant racial group were unaware. These ideas manifest in CRT, where one of the basic tenets is to highlight the voices of people from marginalized groups. Besides Alan Freeman, other pioneers that have contributed to this theoretical framework include Charles Lawrence, Derrick Bell, and Kimberlé Crenshaw, among many others [81-83].

Bell's theory of interest convergence is also important when discussing the history of CRT [82]. Bell argues that progress in civil rights laws only occurs when the interests raised align with the interests of middle and elite classes. For example, Bell explains that desegregation was beneficial to the elites for several reasons, the biggest being the 


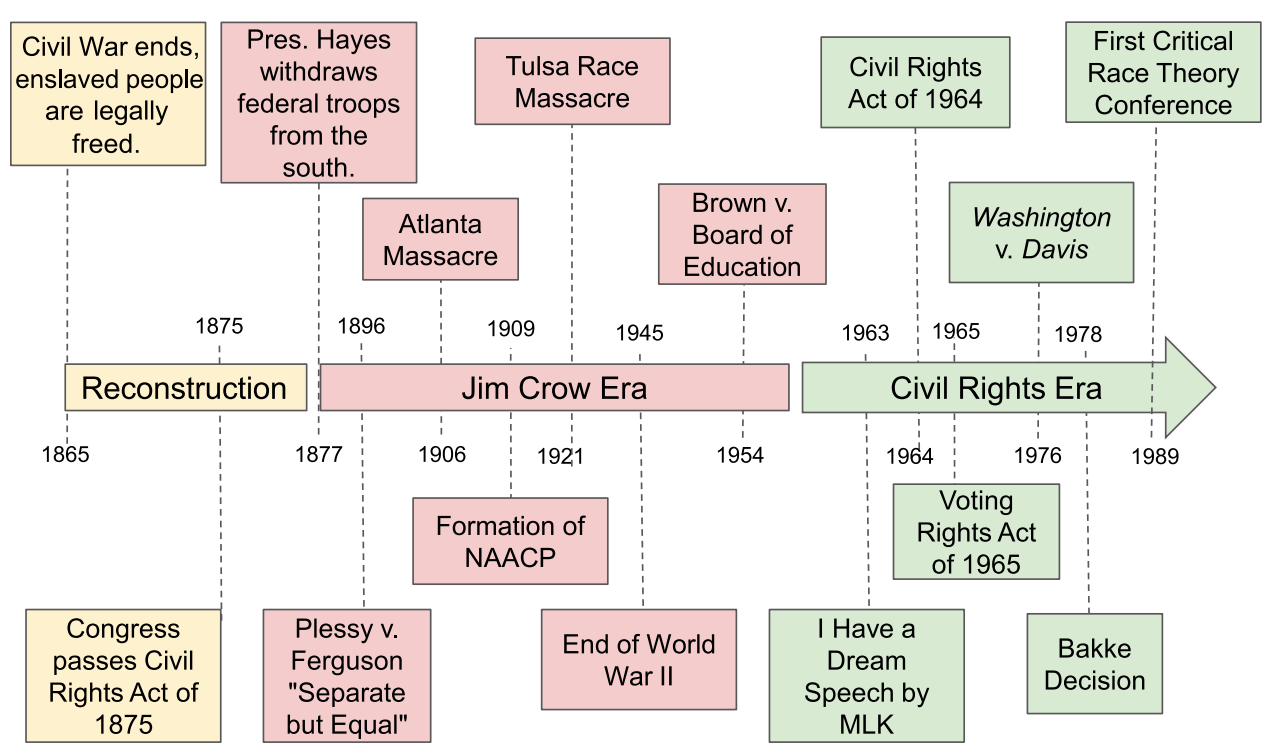

FIG. 1. Historical timeline of events leading to CRT.

threat of the Soviet Union using these divisions against the U.S. both domestically and internationally [84]. Another example is how the emancipation of slavery benefited the elites, since southern states were more behind in industrialization than the northern states due to their reliance on slavery [85]. This means that true change towards equity has only occurred when the interests of the oppressed converge with those of the elites. The concept of interest convergence implies that racism has and will always exist within U.S. society, due to the perseverance of power in the hands of the elite and their ensuing lack of interest to make real changes from which they do not benefit. Bell coined this as racial realism and he argues that even though Black Americans will never attain full equality, they should continue to fight against oppression [86]. Racial realism states that racism is a means of allocating privilege and status within a society. Racial realism is a fundamental value of critical race theory and rejects ideas of liberalism, such as neutrality and color blindness.

These historical developments (Fig. 1), with others, led to a small group of 24 scholars of color meeting together in the summer of 1989. This retreat, organized by Crenshaw, was entitled "New Developments in Critical Race Theory" and led to the formalization of CRT as an intellectual movement. Since then, many scholars have built upon and developed CRT into a rich transdisciplinary theory that can push back against the forces of racism and racial discrimination. Next, we will highlight the basic tenets and themes that make up modern CRT.

\section{Tenets of CRT}

"Race is the child of racism not the father." (Ta-Nehisi Coates)
In this section we will briefly summarize tenets and major themes that make up CRT. There are four major tenets central to CRT: (1) racism is ordinary; (2) civil rights only advance when they align with the interest of the elites; (3) race is socially constructed from products of social relations; and (4) unique voices of color must be heard to understand racism [65]. These fundamental tenets are central to CRT and together help build the central themes of CRT that will be examined in the next section.

Racism is ordinary.-The first tenet of CRT asserts that racism is ordinary and persists in U.S. society. As the quote at the beginning of this section mentions [87], the idea of race could not exist without racism. Historically speaking, racism has always been ordinary in the United States. The history of racism in the United States is vast and began with the introduction of enslaved people from Africa. As a result, many ideologies such as white supremacy have flourished since the founding of the nation. A great number of injustices have been and continue to be committed against African Americans. Many Black people were enslaved and considered property until the emancipation proclamation. After being freed, they continued to face institutionalized racism such as Jim Crow laws [75]. Currently, we live in the "New Jim Crow" of the carceral state [38] where one-third of African American males have a felony conviction [88] and are stripped of many of their rights as a result.

In the past four years, racism has become more apparent due to the rise of white supremacy groups and far right nationalism [89]. Racism and inequality continue to persist in many sectors of U.S. society, including health care [90], education [91], and law enforcement [32] among others. Racism is often thought to be overt, but there are also subtle forms of racism called microaggressions, which continue to 
thrive in U.S. society. Microaggressions are subtle verbal, noverbal, and/or visual insults directed toward People of Color, which are often made unconsciously [92]. Higher education is not exempt from racism, as overt racism and microaggressions have been documented and studied in predominantly white institutions [93]. People of Color majoring in STEM fields continue to face racial microaggressions, which are related to the racial climate of an institution $[94,95]$. There is a need to study the experiences of marginalized students to find solutions and make changes to policy that support them at both the departmental and university levels.

Interest convergence.-The second tenet, known as interest convergence, explains how the interests of People of Color only progress when they converge with the interests of affluent white people. Consequently, when and if that racial progress reaches a point that threatens the dominant group, it will be abrogated [82]. We highlighted broad examples above, but this concept can be applied to other domains. For example, in STEM education research there has been a call by scholars to increase equity and diversity. While this is admirable, the fundamental reasons for doing so are often rooted in economic gains and maintaining U.S. global dominance in science and technology [96]. Whenever the interests of oppressed groups are in opposition with the interests of the dominant group, social progress towards pursuing civil rights is increasingly difficult [82]. It is in the interest of the dominant group for progress to happen slowly, since reaching equality would mean the depreciation of their dominance [97].

Race is socially constructed.-The third tenet argues that race is socially constructed from products of social relations. Although there have been attempts to scientifically prove white supremacy through the eugenics movement, race has no biological significance [98]. Race is socially constructed, meaning racism is a social and cultural problem [99]. Racism serves to sustain and reinforce white-over-color systems that benefit the dominant group.
The dominant group in the U.S. have been and continue to be white people. The fact is that all white people benefit from these systems of racial oppression, including those that consider themselves allies to racially marginalized groups.

To disrupt and eliminate these systems, a majority of society will need to shift ideologically. Taking a group position on racism as opposed to an individual position is important because the dominant group, overall, benefits from marginalizing People of Color [100]. Such systems will not change when viewed individually and must be addressed collectively as a society. To do so the public must be made aware of the prevalence of racism and then work proactively to dismantle the white supremacy which is culturally and systemically embedded within U.S. society. People of Color must recognize and call out microaggressions in real time, to address them. White allies must act to support People of Color by believing them and taking action. In physics, around $77 \%$ of physicists and physics majors are white [26], meaning white allies play the biggest role in supporting underrepresented students.

Uniqueness of $P O C$ voices. - The fourth tenet asserts that to understand the oppressed, their voices must be heard and highlighted. CRT research must highlight the voices of the oppressed to reveal the truth of their experiences. CRT research should also be conducted by, or at the very least co-authored with, scholars of color. By giving People of Color a voice, they may be able to communicate truths to their white counterparts that are unlikely to be known. This is somewhat similar to the idea of double consciousness by Du Bois, where he argues that African Americans have a sort of double consciousness needed to navigate both white and Black culture [101]. To understand the experiences of people from marginalized groups, their voices must be heard, and for their words to be interpreted correctly, scholars of color should be included in the research. These four tenets are summarized in Table II, along with some resources for additional reading.

TABLE II. Summary of the four tenets of critical race theory.

\begin{tabular}{|c|c|c|c|}
\hline Tenet & Definition & Examples & Resources \\
\hline 1 st-Racism is ordinary & $\begin{array}{l}\text { Racism is common and continues to } \\
\text { persist in U.S. society. }\end{array}$ & $\begin{array}{l}\text { New Jim Crow laws } \\
\text { Access to education } \\
\text { Disparities in healthcare }\end{array}$ & $\begin{array}{c}{[32,37,74]} \\
{[30,89,92,93]} \\
{[31,36,88]}\end{array}$ \\
\hline 2nd-Interest convergence & $\begin{array}{l}\text { Civil rights only progress when they } \\
\text { align with the interest of the elites }\end{array}$ & $\begin{array}{l}\text { Emancipation of slavery } \\
\text { Desegregation }\end{array}$ & {$[81,83-85]$} \\
\hline $3 \mathrm{rd}-$ Race is socially constructed & $\begin{array}{l}\text { Race is socially constructed from } \\
\text { products of social relation }\end{array}$ & $\begin{array}{l}\text { Racism sustains and reinforces } \\
\text { white-over-color systems }\end{array}$ & {$[97,98]$} \\
\hline 4th-Uniqueness of POC voices & $\begin{array}{l}\text { To understand the racism, the voices } \\
\text { of those experiencing racism must } \\
\text { be understood. }\end{array}$ & $\begin{array}{l}\text { White people don't experience } \\
\text { discrimination for their race, } \\
\text { making it hard to relate to POC }\end{array}$ & [99] \\
\hline
\end{tabular}




\section{Major themes of CRT}

"Race doesn't really exist for you because it has never been a barrier. Black folks don't have that choice." (Chimamanda Ngozi Adichie)

Building on these tenets, we will explore topics such as differential racialization, the Black and white binary, the function of racism, white privilege, majoritarian stories, and CRT critiques on liberalism and meritocracy. In doing so, we hope to present the reader with a brief synopsis of the major themes that have come out of CRT. These additional major themes of CRT are summarized on Table III along with some additional resources for each.

Differential racialization.-CRT explores the concept of differential racialization, which explains how races that are discriminately targeted, change over time, due to the interests of the white elites. A current example is the rise in discrimination and hate crimes against Asian Americans since the start of the pandemic, due to the blaming of the pandemic on China [37]. These changes in social racial perceptions are not random and are by-products of traditional media, social media, and popular culture $[102,103]$. Weaponizing race is often in line with the political interests of the elites, and racism serves as an ideological tool used by the elites to reinforce their dominance and further their objectives.

Black white binary.-In 1950, 89.9\% of the population were white and $10 \%$ were Black, meaning that $99.6 \%$ of the population in the U.S. were either Black or white [104]. Up until the McCarran-Walter Act in 1952, only immigrants that were legally categorized as white were allowed to enter the U.S. [105]. As a result, racism has historically been viewed and continues to be seen through a Black and white binary; this is fundamentally flawed, as it neglects the unique experiences of non-Black and non-white people.
Racism can no longer be seen as solely Black or white; other ethnic and racial backgrounds need to be considered. CRT recognizes this and has evolved to include several subfields that include disability CRT [106], Latino CRT [107], Asian CRT [108], Tribal CRT [109], and critical indigenous theory [110].

White privilege.-One of the functions of racism is giving the dominant group privileges over other minoritized groups. White privilege describes the benefits of being white in American society and is often hidden from most white Americans [111]. McIntosh identified a total of 46 privileges that white people have over People of Color [112]. Some of these white privileges include their children being given curricular materials that testify to the existence of their race; never being asked to speak for all the people of their racial group; and not having to educate their children to be aware of systemic racism for their own daily physical protection. These privileges still exist for whites that consider themselves allies of People of Color. In order to truly reach equality, these privileges must be abolished, and hence will negatively impact all white people.

Majoritarian stories.-These ideologies discussed are maintained and propagated through majoritarian stories (also known as master narratives). Majoritarian stories are "bundles of presuppositions, perceived wisdoms, and shared cultural understandings persons in the dominant race bring to the discussion of race" (p. 462) [65]. Majoritarian stories privilege white middle- or upper-class heterosexual men by claiming these social identities as normative [113]. They are and have been transmitted through popular culture, media, and education over generations. As a result, a large proportion of the population, including marginalized groups such as People of Color, women, and the $\mathrm{LBGT}^{+}$community, continue propagating majoritarian stories. Examples of a majoritarian stories

TABLE III. Summary of other major ideas of critical race theory.

\begin{tabular}{|c|c|c|c|}
\hline Major themes & Explanations & Examples & Resources \\
\hline Differential racialization & $\begin{array}{l}\text { The interests of white elites determine } \\
\text { how races are discriminately targeted; } \\
\text { targets change over time. }\end{array}$ & $\begin{array}{l}\text { Negative stereotypes against Muslims } \\
\text { after } 9 / 11 \text { due to political tensions } \\
\text { in the Middle East. }\end{array}$ & {$[100-102]$} \\
\hline Black white binary & $\begin{array}{l}\text { Racism is often viewed through a Black } \\
\text { and white binary, neglecting the } \\
\text { unique experiences of other people. }\end{array}$ & $\begin{array}{l}\text { Critical race theory has sub-fields that } \\
\text { include disability CRT, Latino CRT, } \\
\text { and Asian CRT. }\end{array}$ & [103-107] \\
\hline White privilege & $\begin{array}{l}\text { The benefits of being white in American } \\
\text { society that is often invisible to most } \\
\text { white Americans. }\end{array}$ & $\begin{array}{l}\text { White children are given curricular } \\
\text { materials that reflect their race }\end{array}$ & $[108,109]]$ \\
\hline Majoritarian stories & $\begin{array}{l}\text { Stories transmitted through pop culture, } \\
\text { media, and education privileging } \\
\text { white heterosexual men. }\end{array}$ & $\begin{array}{l}\text { Portraying People of Color in movies } \\
\text { that uphold racial stereotypes. }\end{array}$ & {$[64,110-112]$} \\
\hline
\end{tabular}


include the idea that being "different" is a deficit and that meritocracy is how resources should be allocated [114]. CRT challenges majoritarian stories by providing a counternarrative often involving reality [115]. CRT recognizes that being different is valuable, often guiding new perspectives and innovation, and meritocracy is not just based on ability, but also luck and access to opportunities and resources.

Critique to liberalism.-Critical race theory criticizes liberalistic philosophical and political ideologies. Ideals of liberalism, such as consent of the governed and equality before the law, are abundant in U.S. society. Liberalist ideologies like colorblindness, the idea that we should not talk about race due to being in a post-racial America, and neutrality, the idea that discrimination can happen without intent (meaning it has a neutral effect), ignore the facts of racial inequality and exist to keep the status quo intact [116]. These arguments hold that the U.S. is in a post-racial era, where race is no longer a barrier to reaching success. We cannot simply ignore race and treat discrimination as a neutral and "unintentional" consequence of an individual's, or society's, actions.

Critique to meritocracy.-Critical race theory, along with many other philosophical movements, critiques principles of meritocracy, the idea that anyone can succeed if they work hard enough regardless of their beginnings. The fact is that the strongest predictor of "success" is coming from wealth and not talent [117]. Meritocracy is one of the most prevalent and dominant ideologies of our society, and is a direct consequence of capitalism that largely ignores race, class, and gender while arguing that merit is the most important quality to achieve success [118]. Meritocracy serves to justify racial inequalities and even deny their existence [119]. Merit cannot be isolated from socioeconomic status, as the quality of education, living standard, and access to opportunities in themselves are usually determined by socioeconomic forces surrounding an individual.

We have examined four tenets of CRT and other major themes such as differential racialization, white privilege, majoritarian stories, along with critiques of liberalism and meritocracy. There is more to explore for each of these topics and this summary only scratches the surface of this richness of CRT. Building on these ideas, next we will highlight how critical race theory serves as an analytic tool for studying broad racial inequities in education and PER, specifically.

\section{CRT in education}

"Education leads to enlightenment. Enlightenment opens the way to empathy. Empathy foreshadows reform." (Derrick Bell)
Critical race theory is a useful analytic tool that can be used to understand racial inequities in education. CRT explains that racism is ordinary and continues to persist and thrive in the U.S. education system. For example, People of Color have fewer educational opportunities and resources [120-122], higher dropout and lower graduation rates [123], and face disparities in school discipline [124]. U.S. education also remains highly segregated, where most white kids tend to go to mostly white schools and Black kids mostly Black schools [125]. Continued segregation is mostly a function of how deeply intertwined race and property continue to be in the U.S.

Historically speaking, property rights have been more important than human rights in U.S. society. The government acts to protect property, which is the main objective of society. There are many examples of this, from taking Native Americans' lands to enslaved people being considered property. Human rights have always taken a back seat to pursuits of property and the wealth of white elites in U.S. history [126]. This continues to be the case, as an individual's local property taxes and income indicate the quality of educational access their children will have [127]. As a result, the higher the property value and higher the taxes paid lead to more financial resources being given to an individual public school. Since educational content falls under intellectual property copyright laws, schools have to pay for the courses and content they can offer. This limits the quality and quantity of educational content schools can purchase, resulting in less access to content for schools in lower socioeconomic areas [128].

Beyond the issues involving property laws, there are biases against People of Color within the classroom. Students of color are given harder penalties at schools for bad conduct, similar to adult legal punishment of People of Color [129]. Partly contributing to these biases is the fact that $79 \%$ of public-school teachers in the U.S. are white. This does not match the student demographics, where only about $48 \%$ of students are white [130]. Besides diversifying the demographics of teachers, education practices and policies [131] can be used to address racial injustice in education. There has been some success in preparing teachers for diverse populations through using CRT to explain existing inequalities and challenge generic models of teaching education that are not built on theoretical foundations [132].

Critical race theory has also been used to examine racial inequities in higher education [133]. Microaggressions against African American and Hispanic students in predominantly white elite institutions have been found to be commonplace $[93,134,135]$. Unfortunately, faculty of color are not exempt from racial discrimination and also report experiencing microaggressions at primarily white universities [136,137]. Creating a positive racial climate at a university is critical to reducing microaggressions and creating a racially inclusive environment [138]. A positive racial climate leads to positive academic outcomes for 
African Americans, while a negative racial climate is associated with poor academic performance and high dropout rates [93].

\section{Critiques of CRT}

"As Thomas Kuhn has shown, paradigms resist change. It should come as no surprise, then, that Critical Race Theory, which seeks to change the reigning paradigm of civil rights thought, has sparked stubborn resistance." (Richard Delgado)

Like many groundbreaking theoretical frameworks, resistance and critiques to the paradigm shifts of CRT have emerged. External critiques of CRT include accusations of (1) mainstream scholars ignoring the contributions of writers of color; (2) critical theorists hiding behind personal stories and narrative to advance an agenda; and (3) questioning how CRT is valid if Asian and Jewish people have achieved high levels of success [65]. CRT proponents have argued that such comments show a lack of understanding of the movement. They argue that (1) historically speaking, People of Color have been underrepresented and ignored in academia; (2) the only way to understand and fight racism is for victims of racism to be given a voice; and (3) the success of Asian and Jewish people occurred despite an unfair system. Another common critique of CRT is that CRT makes white people look like the enemy or that CRT is racist against white people. These critiques reject systemic racism and often ignore the real history of color in America.

\section{Ongoing challenges to CRT}

Although the CRT movement is thriving, it has been in the national spotlight and has increasingly come under attack. There has been a rise in the right-wing offensive against affirmative action, immigration, hate-speech regulation, and governmental measures that increase People of Color's political representation. Some of these laws and policies are also at risk, with a 6-3 conservative Supreme Court being more likely to rule against these progressive measures. The right-wing attacks CRT, choosing to promote ideas of color blindness and post-racism to mostly white populations. They choose to make white people the victims of such policies while denying systemic oppression of People of Color.

There are several issues that have sharply divided the country, politically speaking, and a post-racial neoliberal agenda has split the difference even more. Some of these issues include (1) race, class, and poverty; (2) policing and criminal justice; (3) hate speech; (4) school curricula; (4) affirmative action and color blindness; and (5) globalization and immigration [65]. Though these issues go beyond the scope of this article, we wanted to mention them briefly because they are real issues on which many people, including physicists, are divided. The orchestrated repudiation of CRT, from the far-right wing, stating that CRT should not be taught in school, even though children build racial biases as early as two years old [139], serves to validate CRT as an effective analytical tool to fight and change systemic oppression. Another useful analytical tool to fight and change systemic oppression is feminist standpoint theory, which we explore below.

\section{B. Feminist standpoint theory}

Feminist standpoint theory formed through feminist scholars thinking and writing about how and by whom knowledge is produced $[68,140,141]$. Feminist standpoint theory, by building upon standpoint theory, is both a theory of knowledge and a methodological research framework. FST is both a way of understanding power dynamics in research, and provides a lens to give epistemic privilege to people in marginalized or oppressed positions. This theory points to ways that people can be better included in physics education, particularly those from marginalized and underserved groups.

\section{Historical context}

The origins of SPT lie in Marxist philosophy, where Marx and Engel viewed the oppressed as having an inherently better understanding of their lives, conditions, and their society as compared to the oppressors $[142,143]$. In Marx's view there were the bourgeoisie, the people in society with financial and social means, and the proletariat, the lower-class people who earn wages and often only have economic means through their own physical labor [143]. In Marx's view, to truly understand the society at large and the experiences of the proletariat (oppressed), you have to seek knowledge creation from them and their own positions, or rather standpoints, collectively in society.

Women philosophers of science and broader scholars (e.g., Harding, Haraway, Collins, Rose) [68,140,144-146] expanded on Marx's ideas to situate women as important knowers in society who have epistemic privilege in understanding their lives and oppression. As Harding put it, FST takes into account "the differences between women's and men's situations which give scientific advantage to those who can make use of the difference" (p. 145) [147]. Early critiques and uses of standpoint theory suggested that the sex, therefore social position, of the scientist even impacted the rigor and conclusions of scientific research. Early studies took aim at issues of biology, primatology, and health outcomes [144,148,149].

Early research on primates (primarily done by men) concluded that all troops were male-dominated and led. However, female primatologists later were able to see the social dynamics beyond the view of the male and discovered more complex social interactions that involved female 


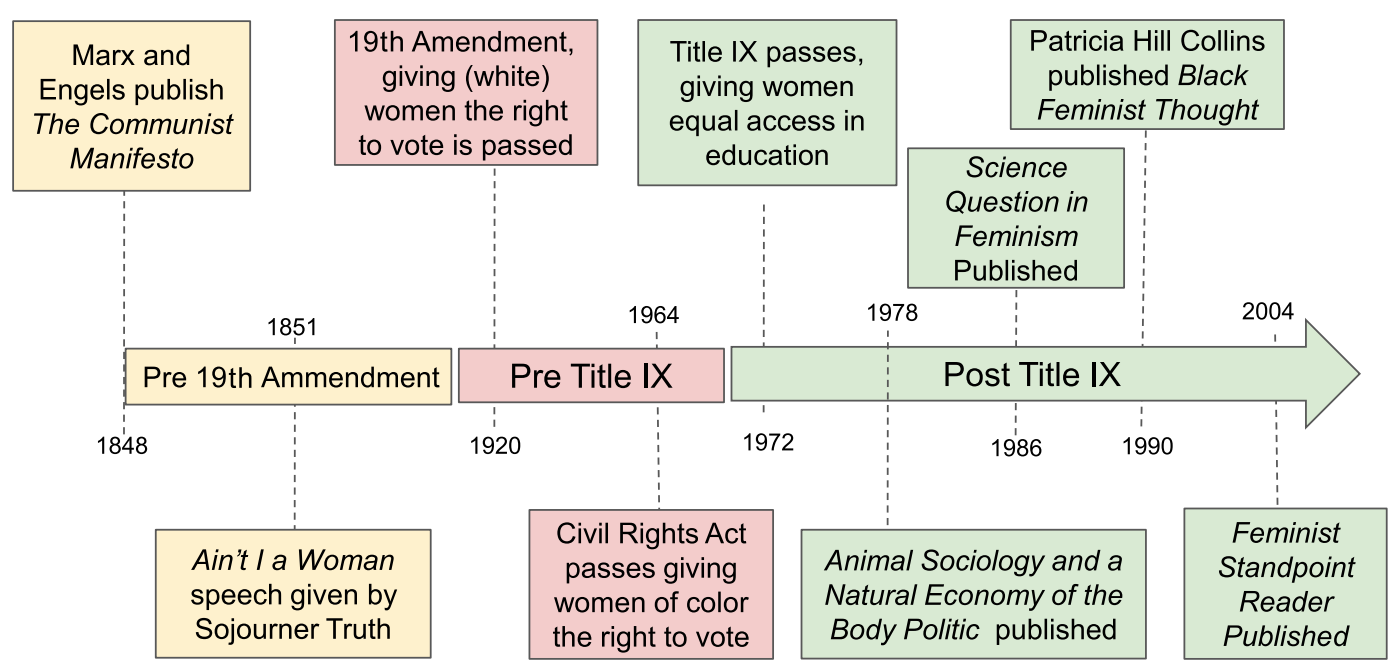

FIG. 2. Timeline of historical events leading to feminist standpoint theory.

primates, suggesting that the male scientists projected their own view of human society on the study of primates $[150,151]$. Other such projected results in science include the conclusion that the leaders of bee colonies, although seen giving birth, were male, when in fact they were female [152]. Beyond arguing that women scientists have this epistemic privilege, or perspective, in their own scientific endeavors, Harding further argues that research itself needs to come from the lives and conditions of women [141]. This is no clearer than in medical trials where women were left out of such studies until the early 1990s [153]. Even recently, during the pandemic of the 2020s, pregnant women were not included in vaccine trials for COVID19, prompting concerns [154]. Additionally, there are other issues with medical trials that also do not include women from all age groups [155].

Patricia Hill Collins, crucially, pushed SPT further in 1990 [140] by arguing the importance of seeing standpoints at intersecting points of identity, such as being both a woman and a Person of Color. This idea, now known as intersectionality, will be discussed further below. However, at this juncture it is important to point out that FST truly can be condensed to SPT, because there are many marginalized standpoints that can be considered. Particularly in physics this includes women [[12,156], Black physicists [22,23], LGBT persons [7], and more. The historical developments of SPT are briefly summarized in Fig. 2.

\section{Tenets of SPT}

“...standpoint theory claims that some kinds of social locations and political struggles advance the growth of knowledge..." (Harding [68], p. 2)

SPT manifests in many ways, including as a sociology of science, a theoretical framework, a philosophy, an epistemology, and more $[68,142,156]$. For the purposes of PER, SPT may be most informative as an applicable theoretical framework and epistemology. Consequently, it is important to understand the tenets of SPT from these perspectives. The tenets of CPT are summarized in Table IV, along with some resources for each tenet.

SPT as an epistemology.-As an epistemological standpoint theory suggests that knowledge is situated in the lives and experiences of people who collectively represent one identity (i.e., women, Black men, transgender people). In other words, knowledge is socially situated [145], meaning the development of knowledge comes from the lived experiences of people. Collectively, groupings of people form their standpoints through their social consciousness or identities [157]. In physics education this could manifest itself in many ways, from first generation students to marginalized groups in the classroom. Such standpoints lead to what Collins calls the outsider within [158]. Essentially, the standpoints of individuals who are not the majority in a group can offer a unique perspective in research. For example, a Latine student in a physics classroom with majority white students would have epistemic privilege in understanding an environment, meaning particular knowledge can only be gained through their perspective, or standpoint. In this way a Latine student in physics would have a double vision (or double consciousness) - their vision as a physics student and that of a Latine person in physics [158]. This core principle of producing knowledge from the perspective of the oppressed runs parallel to the fourth tenet of CRT. Standpoint theory, however, is not just an epistemic idea to work from, but also a method of inquiry to employ as a theoretical framework.

SPT as a theoretical framework.-Standpoint theory is a strong tool in the construction, analysis, and reporting of scientific evidence in education. Using standpoint theory as a theoretical framework asserts asking particular questions throughout a study as suggested by Harding in a 2016 
TABLE IV. Summary of standpoint theory.

\begin{tabular}{|c|c|c|c|}
\hline Major themes & Explanations & Examples & Resources \\
\hline $\begin{array}{l}\text { Socially situated } \\
\text { knowledge }\end{array}$ & $\begin{array}{l}\text { Development of knowledge comes from } \\
\text { the lived experiences of people }\end{array}$ & $\begin{array}{l}\text { The knowledge of being a first-generation } \\
\text { student is held by first generation students. }\end{array}$ & {$[142,155]$} \\
\hline Outsider within & $\begin{array}{l}\text { Someone in a group who does not fit the } \\
\text { majoritarian demographic, has a } \\
\text { unique perspective in the group. }\end{array}$ & $\begin{array}{l}\text { A Latine student in a physics classroom has a } \\
\text { different perspective about studying physics } \\
\text { than their peers. }\end{array}$ & {$[156]$} \\
\hline Double vision & $\begin{array}{l}\text { A person's perspective of both being in a } \\
\text { group, and an outsider to the group. }\end{array}$ & $\begin{array}{l}\text { A woman in physics has the vision of being a } \\
\text { physicist and a woman in physics. }\end{array}$ & {$[156]$} \\
\hline \multicolumn{4}{|c|}{ As a theoretical framework } \\
\hline $\begin{array}{l}\text { Position of knowledge } \\
\text { creation }\end{array}$ & $\begin{array}{l}\text { Asks where knowledge is being produced } \\
\text { and who is creating the knowledge. }\end{array}$ & $\begin{array}{l}\text { When studying underserved groups in physics } \\
\text { you should talk to those groups. }\end{array}$ & {$[156]$} \\
\hline Benefits of research & Ask who benefits from the research. & $\begin{array}{l}\text { Are the groups being studied benefiting from } \\
\text { the research or the careers of the researchers? }\end{array}$ & {$[156]$} \\
\hline
\end{tabular}

interview [159]. Harding points to three questions one must ask to employ standpoint theory: (1) From who is the knowledge being produced?, (2) who has to pay the costs of the research?, and (3) who will get the benefits of the research? In PER, the first (1) question asks a scholar to think about where the knowledge is being generated. For example, if you want to know about women's lives in physics you should consider asking women. Within this inquiry, you would seek knowledge from their perspective without comparisons to others [160]. The second (2) question suggests the importance of the impact of the research, acknowledging the toll it may take on participants both physically and emotionally. The third (3) question seeks to understand who gains from the work. For example, will this work actually benefit the population being studied, or is it only being done for the career advancement of the scholar? Lastly, standpoint theory would assert the importance of interrogating the identity of the person asking the question [156]. This would suggest the importance of understanding if the standpoint of the individual is situated in a place to discover knowledge from their participants. This might be particularly salient for a white scholar studying People of Color, or a man studying women.

\section{Critiques of SPT}

"Feminist standpoint theory remains highly controversial: it is widely advocated, used to guide research and justify results, and yet it is also vigorously denounced" (Harding [68], p. 1)

Standpoint theory is not without its critiques, or limitations, in the design and approach a scholar takes to their research.
Three such critiques will be discussed here as laid out by Harding in 2009 and 2017 [156,159].

The first critique is about how standpoint theory extends itself to the positionality of the researcher before a question is even asked [156]. This is counterintuitive to how science is traditionally thought to be done, asking questions for which we want answers without regard to who we are as people or our social locations. The counterpoint from standpoint theorists would be that there is always an origin to questions, such as being from the directives of the funder or sponsor. However, the claim that our standpoints influence the questions we ask and the knowledge that is produced is still in conflict with the traditional-minded objectivity applied to the sciences, particularly the physical sciences.

The second critique is SPT's reliance on the development of a group consciousness to develop knowledge [156]. In this way SPT ignores the individual and assumes total reliance on group think, or experience. As Harding points out, "Standpoint theory articulates the importance of a group's experience, of a distinctive kind of collective consciousness, which can be achieved through the group's struggles to gain the kind of knowledge that they need..." (Harding [156], p. 12). This thinking erases the individualized experience and suggests all we have are the experiences from being in a collective group. Clearly, individual experiences can create knowledge, as is evident by many case studies in PER [12,20]. In this light, knowledge may need to be viewed as created by individuals and groups and not just the individuals [156,159].

The third and final critique presented here is that standpoint firmly suggests that knowledge is socially situated. Early studies on primates, human nature, and 
psychology [152] clearly demonstrate how social values of androcentrism and white supremacy can influence how we view groups like women, People of Color, LGBT persons, and more. However, such influence of human proclivities is hard to defend when considering something such as Newton's laws, where empirical evidence and written theory have demonstrated that this is knowledge that predicts nature, and accurately. The standpoint theorist might push back on this and argue that Newton's laws were only apparent because of our own experiences but failed to explain things we cannot see (the quantum level of matter for instance). But the development of quantum mechanics came from paradoxes that could not be explained and demanded further investigation, potentially refuting the stance of SPT. A halfway point might be to suggest that some knowledge is indeed socially situated, but other knowledge is not. In PER, standpoint theory could be argued in that culture and context impact the teaching methods we should use, and we should consider including research and ideas from marginalized scholars in PER; however, this might conflict with learning theory, which may suggest there are universal truths in the pursuit of educating students.

\section{SPT today}

Standpoint theory is not just an artifact of the 20th century but is still in use today by researchers around the world, no matter how "controversial" it might be. This includes PER which will be discussed below. In recent years SPT has grown to address, critique, and bolster other fields of research. This has included creating an indigenous SPT for research considering the people of Africa [161], addressing the field of psychology and how SPT could improve their investigations [162], and uncovering how new standpoints could improve the clinical practice of doctoral students who conduct therapy with diverse populations [163]. SPT is relevant today and can be expanded to fit the many dynamics of our changing world, from epistemic musings to education in physics.

\section{Intersectionality}

"Intersectionality draws attention to invisibilities that exist in feminism, in anti-racism, in class politics, so, obviously, it takes a lot of work to consistently challenge ourselves to be attentive to aspects of power that we don't ourselves experience." (Kimberlé Crenshaw)

Intersectionality is its own fully developed theory that stands as a peer to both CRT and SPT. However, central components of intersectionality are also pivotal to the theories discussed here. Elements of intersectionality are discussed below, however, a stronger and more rigorous treatment is needed for the PER literature. The importance of intersectionality is that it considers how multiple factors of oppression interact and are unique for different people. Intersectionality considers that people may be oppressed for various factors simultaneously, such as race, gender, and class. For example, Black Women face discrimination for being both Black and women, and an LGBT Indigenous person can face disadvantages and discrimination for their sexual orientation, gender identity, and ethnic or racial background. When considering theories such as CRT and SPT it is important to recognize the impact of these intersections in people's lives and accommodate them in research, particularly PER.

The term intersectionality was coined by Crenshaw in her seminal work on how the racism and sexism Black women experience intersect into a unique superposition of both that could not be reduced to either sexism or racism [83]. However, the idea of combined identities dates back much further. This includes the speech "Ain't I a Woman" by abolitionist and formerly enslaved person Sojourner Truth at the 1851 Women's Convention in Akron Ohio [164]. Her short speech emphasized how as a Black woman she was not treated the same as white women. More recent discussions of the importance of combining multiple perspectives (identities) together can also be seen in the Combahee River Collective which formed in 1974 [165].

This collective was "actively committed to struggling against racial, sexual, heterosexual, and class oppression, and [they saw their] particular task as the development of integrated analysis and practice based upon the fact that the major systems of oppression are interlocking" (p. 15) [165]. The leader and participants of the collective recognized the sexism in many Black rights organizations, the racism in many women's rights organizations, and the homophobia that existed in both. Consequently, they created their own space which could address all of their grievances in a way that we would call intersectional today. Lastly, and of course, Collins' work pushing SPT to embrace Black feminism is also a strong example of intersectionality before the term was widely employed [140].

\section{CRT AND FST IN PHYSICS EDUCATION RESEARCH}

Understanding the origins and current applications of CRT and FST, although a promising start, is not enough for physics education researchers. We also need to think about how we can apply these frameworks and theories within our work to produce better scholarship. The end goal of such scholarship is, of course, supporting, recruiting, and retaining a more diverse group of students into our field broadly, and specifically within the ranks of PER. To have this discussion, it is first important to see how CRT and SPT have been applied so far and how they could be applied in future studies. 


\section{A. CRT in PER}

Critical race studies in physics are not new. There has been a lot of work done on race and gender disparities through a physics identity lens, a theoretical framework involving a person's identity, recognition, and performance or competence beliefs $[166,167]$. Work has been done to expand physics identity into a critical physics identity lens, by adding relational, ideational, and material resources [168], which were found to significantly impact People of Color's physics identity [23].

The majoritarian story in physics, as in other sciences, is that physics is bias free and that a good idea can be debated by anyone. Counterstories allow us to see that such ideals are not upheld, and that being a Person of Color may mean your ideas, no matter how intelligent, may be unheard and unconsidered [169]. Many Black and Latine graduate students in physics report being the only person of their ethnicity in their program, highlighting the need to diversify student populations [170]. The challenges for racially underrepresented groups continue on for those who graduate their doctoral programs and become postdoctoral scholars [171]. Issues of racism in physics are not just domestic issues; they also exist abroad, making this discussion relevant to international studies on physics [172].

Isolation and microaggressions will continue to affect those who become physics faculty, especially Women of Color [173]. Women of Color in physics face implicit biases like being asked "if they are physicists" and explicit biases like not getting hired, even while exceeding qualifications [174]. The prevalence of these issues should be clear, since Women of Color overwhelmingly attend predominantly white institutions [175]. Black women face challenges establishing meaningful relationships with their peers and seek balance that includes both science and family [24]. Physics, like many sciences, continues to be dominated by white empiricism, the ideology that only white people (particularly white men) have the fundamental capacity for objectivity, resulting in noninclusive environments for Women of Color [176]. In spite of these challenges, Women of Color persist in physics by employing multiple forms of agency, including several navigational strategies such as seeking environments that enable success, combating isolation using peer networks, remembering their passion for science, and engaging in activism [177].

Though critical theories have been used in PER, most have not referenced CRT explicitly. We want to take a moment to compliment and critique the few studies that have explicitly used CRT as a theoretical framework in PER. The first publication that used CRT explicitly in PER was a qualitative study on the experiences of six Black women physicists. Authors found that these women experienced exclusion from study groups and faced challenges of socialization in STEM [22]. Being invited to engage in science at an early age and participating in science research programs were fundamental to why these women had chosen physics [22]. Two quantitative CRT studies in PER have been published in 2020 and 2021. One found that all students, especially People of Color, in courses that use learning assistants have lower drop, failure, and withdrawal rates [178]. The other found that racial and gender differences in student attitudes on physics persist and, in some cases, worsen after introductory physics [179].

Our main critique on current and future work using CRT in PER has to do with who is getting the resources to generate the knowledge. As discussed earlier, one of the fundamental tenets of CRT is to give People of Color a voice, and we believe that researchers of color should be included in the research methods and analysis so they may contribute to the production of knowledge. Ideally, scholars of color should be funded for conducting CRT research, or at least be invited (and paid) to participate in those studies.

\section{B. SPT in PER}

Feminist standpoint theory has primarily been employed in PER by the second author of this paper $[2,3,7,11-13,16]$, but has also manifested itself in a recent paper on Black and Latinx students in STEM [170]. Through an in-depth constructivist grounded theory study on graduate women in physics and astronomy, the second author employed feminist standpoint theory to capture their lived experiences directly from their lives, and to build knowledge from that collective social consciousness $[11,12,156]$. FST impacted the study in multiple ways. The primary, and most important, is that the entirety of the locus of knowledge production came from women's lives. Men were not included, interviewed, or used as a comparison point to these women's experiences. Instead, only their voices and perspectives were heard in the creation of knowledge and understanding through their interviews.

Another impact of SPT concerns how the data are analyzed and understood. Primary to the data collection was member checking. Participants were allowed to re-read their transcripts and ensure they were accurate to their experiences. They also had the ability to follow up with emails, or virtual conversations to clarify or expand their stories. Lastly, discussions of participant experiences were always framed from their direct voices. If they experienced something to the authors that seemed to be discrimination, but they did not describe it as such, it was not coded or understood to be discrimination. Knowledge production came directly from their lives and their understanding of their own lives.

The findings were many and explored topics of gendered discrimination, career pathways, the roles of mentorship, how various forms of capital influenced their access to physics, and educational supports, among others. What was crucial in these results is they were not juxtaposed to a 
majority group but only focused on the lives of women. The results have been impactful in the literature, partially influencing an important quantitative study on gender discrimination experienced by women in physics [55].

\section{How to apply CRT and SPT in PER}

This paper has reviewed CRT and FST overall and in PER thus far. Now we want to offer the readers a guide into conducting CRT and FST research in PER. As described above, it is important to ask questions before you do research, such as: who is doing the research, how do you relate to the people being researched, and who benefits from the research? Quantitative and qualitative research in PER rely on theoretical frameworks to measure and interpret results. When conducting critical quantitative and qualitative research, implicit ontological and epistemological assumptions must be examined explicitly [6]. Here we will provide suggestions for using CRT and FST in both quantitative and qualitative research which are neatly summarized in Fig. 3.

\section{CRT and SPT in quantitative research}

Quantitative PER, just like qualitative PER, relies on theoretical frameworks for interpreting results. Historically speaking, many statistical models used in PER, and broadly in many other disciplines, originate from the eugenics movement [180]. Galton, Pearson, and Fisher, all of whom shaped much of the modern statistics used in today's research, were eugenicist and white supremacists. This link between methodology and racism means researchers need to decouple racist ideologies from their statistical models and critically consider their ontological and axiological assumptions [181]. Quantitative CRT (also known as Quantcrit) research is relatively new compared to qualitative CRT research. Gillborn et al. argue there are five tenets to conducting Quantcrit research, which are [182]

1. The centrality of racism as a complex and deeply rooted aspect of society that is not readily amenable to quantification.

2. The acknowledgment that numbers are not neutral and they should be interrogated for their role in promoting deficit analyses that serve white racial interests.

3. The reality that categories are neither 'natural' nor given and so the units and forms of analysis must be critically evaluated.

4. The recognition that voice and insight are vital: data cannot "speak for itself" and critical analyses should be informed by the experiential knowledge of marginalized groups.

5. The understanding that statistical analyses have no inherent value but they can play a role in struggles for social justice.

The first tenet to Quantcrit is included in the first tenet of CRT and adds that racism is difficult to quantify. The first tenet of Quantcrit is also in line with calls for more methods that consider the intracategorical complexities of every research participant [183]. The second tenet stresses that numbers are not neutral and should be critically examined for themes promoting white supremacy and other majoritarian stories. Third, the units and instruments of the analysis must also be critically evaluated. The fourth tenet points to the importance of voice and insight, meaning data and critical analysis should be informed by the experiences of people from marginalized groups. The

\begin{tabular}{|c|c|c|}
\hline & Critical Race Theory & Standpoint Theory \\
\hline 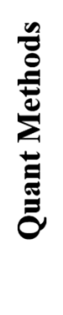 & $\begin{array}{l}\text { 1. Complexity and deep roots of } \\
\text { racism are hard to quantify } \\
\text { 2. Numbers are not neutral } \\
\text { 3. Units and forms of analysis should } \\
\text { be evaluated critically } \\
\text { 4. Experiential knowledge of BIPOC } \\
\text { should inform analysis. } \\
\text { 5. Statistical Analysis can contribute } \\
\text { to social justice }\end{array}$ & $\begin{array}{l}\text { 1. Ask multiple questions about } \\
\text { identity } \\
\text { 2. Don't compare majority groups to } \\
\text { under resourced groups unless it is } \\
\text { an initial baseline analysis } \\
\text { 3. Collect data on underlying variables } \\
\text { related to social positionality }\end{array}$ \\
\hline 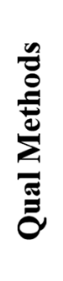 & $\begin{array}{l}\text { 1. The intercentricity of race and } \\
\text { racism with other forms of } \\
\text { subordination. } \\
\text { 2. Challenge dominant ideologies } \\
\text { 3. Commitment to Social Justice } \\
\text { 4. Centrality of experiential } \\
\text { knowledge of BIPOC } \\
\text { 5. Transdisciplinary Perspective }\end{array}$ & $\begin{array}{l}\text { 1. Build knowledge from the lives of } \\
\text { the oppressed } \\
\text { 2. Take participants word and present } \\
\text { results from their perspective } \\
\text { 3. Allow participants to review } \\
\text { research for clarity } \\
\text { 4. Ask contextual questions not } \\
\text { necessarily related to physics }\end{array}$ \\
\hline
\end{tabular}

FIG. 3. Summary of how to apply CRT and SPT in qualitative and quantitative research. 
fifth and final tenet recognizes that Quantcrit can play a major role in social justice, if done appropriately. These tenets are all in line with the tenets and major ideas discussed in the literature review and should be considered by any future Quantcrit researcher. Quantcrit researchers must ontologically consider history, social, political, and economic relations for their work to be effectively used for social justice [184]. These ideas are important throughout the entire research process, from the construction of survey instruments to the analysis, to publishing articles.

For conducting Quantitative STP, there are also guiding principles that need to be considered by the researcher. The first principle is to ask multiple questions about identity. Identity is complicated and it is important to understand the standpoint an individual comes from, and the diversity of voices representing a particular social category. For instance, when asking about gender, it is important to ask about identity, expression, and assignment at birth. The second principle is do not compare majority groups to underresourced groups unless you are conducting an initial baseline analysis. Most research on underserved groups compares them to their relatively well-resourced majority peers. This is an inequitable juxtaposition. Instead, it is important to look at across group differences and experiences. For example, if you are studying women in physics, you can look at People of Color vs white women, or LGBT women vs non-LGBT women. The third guiding principle is to collect data on underlying variables related to social positionality (i.e., income, working through college, food insecurity). Context matters, and standpoint theory includes understanding the relative social positions people hold, and how those impact their standpoint for better or for worse.

\section{CRT and SPT in qualitative research}

Qualitative CRT research has been formalized for several decades and spans most of what currently makes up CRT research. Qualitative CRT research methods in education follow five critical elements, which are as follows [113]:

1. The intercentricity of race and racism with other forms of subordination.

2. The challenge of dominant ideology.

3. The commitment to social justice.

4. The centrality of experiential knowledge.

5. The transdisciplinary perspective.

The first element, just as in Quantcrit, states that race and racism should foreground every aspect of the research process, while adding the importance of factoring in the intersectionality of other forms of subordination due to gender and class [185]. Second, qualitative CRT should challenge claims that educational institutions make about being colorblind and offering equal opportunities. The third element is having a social research agenda that leads to eliminating or reducing discrimination and empowering subordinated marginalized groups. Fourth, the experiences of People of Color are central to analyzing and understanding racial subordination. Fifth, qualitative CRT is transdisciplinary and can be drawn from fields outside of education. These elements for qualitative CRT are like the tenets for Quantcrit, since both draw on the broader framework of CRT.

STP theory has been historically grounded in qualitative research methods, with a primary focus on considering what is standpoint theory, why it is relevant, and what it adds to science studies [186]. When employing SPT in qualitative research, it is both important to consider questions around who the researcher is (their perspective, purpose of doing the research, and how knowledge is being generated) and who the subjects are (their perspectives, how their knowledge is being captured, and what costs or benefits the incur). In this work it is crucial that data collection, and findings, are generated from the group in question, and not their oppressors. It is also important to consider their lived experiences and perspectives as valid and true. Part of this process includes allowing participants to review transcripts, add to the transcripts, and retract or change ideas or their experiences that were not captured fully. Lastly, the context of their lives is important. It is not enough to ask about the research question at hand; one must seek to understand who they are and where they come from when capturing their voices.

\section{FUTURE DIRECTIONS}

Physicists can act as a community to dismantle, albeit little by little, systemic forms of racism and sexism. A meta-analysis involving underrepresented students of color in STEM found that three sociocultural community characteristics, namely, (a) racial (and gender) climate, (b) pedagogical strategies, and (c) mentorship and advising, are significant factors in student's academic success [187]. In other words, a positive racial and gender climate, pedagogical strategies that improve inclusion, and support through mentoring is critical to supporting marginalized groups $[134,188,189]$. Some research on these topics has been conducted in PER, specifically on how pedagogical strategies may improve equity for marginalized students $[190,191]$, though the pervasive use of these research-based instructional strategies is not widespread [192]. Some critical studies in PER suggest that breaking down the harmful ideologies such as "physics culture is not influenced by systems of oppression" [23] and instead expanding the PER community's knowledge of scholars of color's experiences [22] is a necessity for improving equity in physics. Further research on racial and gender climates in physics faculty and departments, and how these impact People of Color is imperative for further progress in diversity, equity, and inclusion.

Other groups, communities, and ideas would also benefit from careful and critical consideration in PER. The list is extensive; however, these authors would like to suggest 
further investigations into students with disabilities, LGBT persons, first generation college students, and low-income students at the intersections of their many varied identities. Within this, an examination of queer theory in PER, intersectionality in PER, and an understanding of neoliberal capitalist forces in physics would also enhance the field of PER.

\section{CONCLUSION}

In this article we have provided a brief yet comprehensive review of CRT and SPT and how they connect and may be used in PER. We started by introducing the broad gender and racial issues that are prevalent in U.S. society, including academic settings. Then we provided historical context and information on the tenets and major ideas that form CRT and SPT. After discussing each theoretical framework in depth, we reviewed published PER critical studies on gender and race, followed by suggestions for applying them. Finally, we discussed future studies that need to be conducted in order to continue combating the racism and sexism which are prevalent in academia and in America at large.

There are several purposes we hope this paper can achieve. The first is to educate the physics community on these theoretical frameworks along with how they connect to larger societal issues. By achieving this purpose, future PER scholars looking to use these critical theoretical frameworks have a starting place for doing CRT and SPT in their research. The second was to stress the importance of thinking critically about how race and gender interact in university settings and academic research. This is especially important for white physicists to be aware of, since they make up the majority of physicists. The final purpose of this paper was to review critical studies into physics and provide suggestions for future work using CRT and SPT. Studies involving race and gender need to be done carefully and methodically while involving participants and researchers of marginalized backgrounds.

Future work will bring further important social and epistemological theories into PER to enhance our current work. Ideas from interdisciplinary fields have historically been important in the continuing growth of PER. We consider continuing this tradition as an important step in sustaining the field.

\section{ACKNOWLEDGMENTS}

The authors would like to thank the National Sciences Foundation Building Capacity in Science Education Research program for supporting this work under Grant No. 2023234.
[1] A. V Knaub, M. Jariwala, C. R. Henderson, and R. Khatri, Experiences of postdocs and principal investigators in physics education research postdoc hiring, Phys. Rev. Phys. Educ. Res. 14, 010152 (2018).

[2] R. S. Barthelemy, M. McCormick, C. R. Henderson, and A. Knaub, Educational supports and career goals of five women in a graduate astronomy program, Phys. Rev. Phys. Educ. Res. 16, 010119 (2020).

[3] R. S. Barthelemy, C. Henderson, and M. L. Grunert, How do they get here?: Paths into physics education research, Phys. Rev. ST Phys. Educ. Res. 9, 020107 (2013).

[4] B. Van Dusen, R. S. Barthelemy, and C. Henderson, Educational trajectories of graduate students in physics education research, Phys. Rev. ST Phys. Educ. Res. 10, 020106 (2014).

[5] R. Scherr, Never mind the gap: Gender-related research in physical review physics education research, 2005-2016, Phys. Rev. Phys. Educ. Res. 12, 020003 (2016).

[6] L. Ding, Theoretical perspectives of quantitative physics education research, Phys. Rev. Phys. Educ. Res. 15, 020101 (2019).

[7] R. S. Barthelemy, $\mathrm{LGBT}^{+}$physicists qualitative experiences of exclusionary behavior and harassment, Eur. J. Phys. 41, 065703 (2020).
[8] A. J. Gonsalves, Exploring how gender figures the identity trajectories of two doctoral students in observational astrophysics, Phys. Rev. Phys. Educ. Res. 14, 010146 (2018).

[9] A. J. Gonsalves, "Physics and the girly girl-There is a contradiction somewhere": Doctoral students' positioning around discourses of gender and competence in physics, Cult. Stud. Sci. Educ. 9, 503 (2014).

[10] A. J. Gonsalves, Gender and doctoral physics education: Are we asking the right questions?, in Doctoral Education: Research-Based Strategies for Doctoral Students, Supervisors and Administrators (Springer, New York, 2011), pp. 117-132.

[11] R. Barthelemy, M. McCormick, and C. Henderson, Barriers beyond equity: An exploratory study of women graduate students' career pathways in astronomy, Int. J. Gender, Sci. Technol. 7, 57 (2015), http://genderandset .open.ac.uk/index.php/genderandset/article/view/371.

[12] R. S. Barthelemy, M. McCormick, and C. Henderson, Gender discrimination in physics and astronomy: Graduate student experiences of sexism and gender microaggressions, Phys. Rev. Phys. Educ. Res. 12, 020119 (2016).

[13] R. S. Barthelemy, M. L. Grunert, and C. R. Henderson, The graduate research field choice of women in academic physics and astronomy: A pilot study, AIP Conf. Proc. 1513, 66 (2013). 
[14] S. Kanim and X. C. Cid, Demographics of physics education research, Phys. Rev. Phys. Educ. Res. 16, 020106 (2020).

[15] A. V Knaub and R. Barthelemy, Persistence and career choices of female Finnish university physics students, in Proceedings of the 2018 Physics Education Research Conference Washington, DC (AIP, New York, 2018).

[16] R. S. Barthelemy and A. V Knaub, Gendered motivations and aspirations of university physics students in Finland, Phys. Rev. Phys. Educ. Res. 16, 010133 (2020).

[17] E. V Patridge, R. Barthelemy, and S. R. Rankin, Factors impacting the academic climate for LGBQ STEM faculty, J. Women Minorities Sci. Eng. 20, 75 (2014).

[18] T. J. Atherton, R. S. Barthelemy, W. Deconinck, M. L. Falk, S. Garmon, E. Long, M. Plisch, E. H. Simmons, and K. Reeves, LGBT Climate in Physics: Building an Inclusive Community (American Physical Society, College Park, MD, 2016).

[19] T. Atherton, R. Barthelemy, W. Deconinck, E. Long, D. Parno, M. Ramsey-Musolf, and E. H. Simmons, Supporting LGBT+ Physicists: A Best Practices Guide for Departments (2013), https://lgbtphysicists.org/files/ BestPracticesGuide.pdf.

[20] M. McCormick, R. Barthelemy, and C. Henderson, Women's persistence into graduate astronomy programs: The roles of support, interest, and capital, J. Women Minorities Sci. Eng. 20, 317 (2014).

[21] M. McCormick and R. S. Barthelemy, Excluded from "inclusive" communities: LGBTQ youths' perception of "their" community, J. Gay \& Lesbian Soc. Serv. 33, 103 (2021).

[22] K. Rosa and F. M. Mensah, Educational pathways of black women physicists: Stories of experiencing and overcoming obstacles in life, Phys. Rev. Phys. Educ. Res. 12, 020113 (2016).

[23] S. Hyater-Adams, C. Fracchiolla, T. Williams, N. Finkelstein, and K. Hinko, Deconstructing black physics identity: Linking individual and social constructs using the critical physics identity framework, Phys. Rev. Phys. Educ. Res. 15, 020115 (2019).

[24] S. Fries-Britt and K. M. Holmes, Prepared and progressing: Black women in physics, in Black Female Undergraduates on Campus: Successes and Challenges (Emerald Group Publishing Limited, Bingley, UK, 2012).

[25] A. M. Porter and R. Ivie, Women in Physics and Astronomy, 2019 (AIP, New York, 2019).

[26] P. J. Mulvey and S. Nicholson, Physics Bachelor's Degrees: 2018. Results from the 2018 Survey of Enrollments and Degrees (AIP Statistical Research Center, College Park, MD, 2020).

[27] P. J. Mulvey, S. Nicholson, and J. Pold, Trends in Physics PhDs: Results from the 2019 Survey of Enrollments and Degrees and the Degree Recipient Follow-Up Survey for the Classes of 2017 and 2018 (AIP Statistical Research Center, College Park, MD, 2021).

[28] R. Ivie, G. Anderson, and S. White, African Americans \& Hispanics among Physics \& Astronomy Faculty: Results from the 2012 Survey of Physics \& Astronomy DegreeGranting Departments (AIP Statistical Research Center, College Park, MD, 2014).
[29] T. Shapiro, T. Meschede, and S. Osoro, The Roots of the Widening Racial Wealth Gap: Explaining the BlackWhite Economic Divide (Research and Policy Brief February 2013), https://drum.lib.umd.edu/bitstream/ handle/1903/24590/racialwealthgapbrief.pdf.

[30] T. C. Howard, Why Race and Culture Matter in Schools: Closing the Achievement Gap in America's Classrooms (Teachers College Press, New York, NY, 2019).

[31] H. Mead, L. Cartwright-Smith, K. Jones, C. Ramos, K. Woods, B. Siegel et al., Racial and Ethnic Disparities in US Health Care: A Chartbook (Commonwealth Fund, New York, NY 2008).

[32] C. Chaney and R. V Robertson, Racism and police brutality in America, J. African Am. Stud. 17, 480 (2013).

[33] E. A. Shrider, M. Kollar, F. Chen, and J. Semega, Income and Poverty in the United States: 2020, Current Population Reports, US Census Bereau (2021), https://www.census .gov/content/dam/Census/library/publications/2021/demo/ p60-273.pdf.

[34] A. Bishaw and J. Semega, Income, Earnings, and Poverty Data from the 2007 American Community Survey (US Department of Commerce, Economics and Statistics Administration, Washington, DC, 2008).

[35] T. Ross, G. Kena, A. Rathbun, A. KewalRamani, J. Zhang, P. Kristapovich, and E. Manning, Higher Education: Gaps in Access and Persistence Study (Higher Education Policy for Minorities in the United States, 2012), http://hdl.handle.net/10919/100555.

[36] CDC, Hospitalization and Death by Race/Ethnicity (Centers for Disease Control, Atlanta, GA, 2021).

[37] H. Tessler, M. Choi, and G. Kao, The anxiety of being Asian American: Hate crimes and negative biases during the COVID-19 Pandemic, Am. J. Crim. Justice 45, 636 (2020).

[38] M. Alexander, The new Jim Crow, Ohio St. J. Crim. L. 9, 7 (2011), https://heinonline.org/HOL/LandingPage?handle= hein.journals/osjc19\&div=5\&id=\&page $=$.

[39] R. T. Lee, A. D. Perez, C. M. Boykin, and R. MendozaDenton, On the prevalence of racial discrimination in the United States, PLoS One 14, e0210698 (2019).

[40] D. Bobbitt-Zeher, Gender discrimination at work: Connecting gender stereotypes, institutional policies, and gender composition of workplace, Gend. Soc. 25, 764 (2011).

[41] D. N. Beede, T. A. Julian, D. Langdon, G. McKittrick, B. Khan, and M. E. Doms, Women in STEM: A gender gap to innovation, Econ. Stat. Adm. Issue Br. 04-11 (2011).

[42] R. E. Morgan and G. Kena, Criminal victimization, 2018, Bur. Justice Stat. 253043 (2019), https://bjs.ojp.gov/ content/pub/pdf/cv18.pdf.

[43] W. M. Williams and S. J. Ceci, National hiring experiments reveal 2: 1 faculty preference for women on STEM tenure track, Proc. Natl. Acad. Sci. U.S.A. 112, 5360 (2015).

[44] F. D. Blau and L. M. Kahn, Gender differences in pay, J. Econ. Perspect. 14, 75 (2000).

[45] M. J. Budig and P. England, The wage penalty for motherhood, Am. Sociol. Rev. 66, 204 (2001).

[46] J. Cimpian, How our education system undermines gender equity, Brown Center Chalkboard (2018), 
https://www.brookings.edu/blog/brown-center-chalkboard/ 2018/04/23/how-our-education-system-underminesgender-equity/.

[47] J. A. Jacobs, Gender inequality and higher education, Annu. Rev. Sociol. 22, 153 (1996).

[48] J. Hatch, Gender pay gap persists across faculty ranks, Chron. High. Educ. 63, 30 (2017), https://www.chronicle .com/article/gender-pay-gap-persists-across-faculty-ranks/ \#: :text=Faculty $\% 20$ salaries $\% 20$ increased $\% 202.8 \%$ 20percent, closing\%20the $\% 20$ gender $\% 20$ pay $\% 20$ gap.

[49] M. Black, K. Basile, M. Breiding, S. Smith, M. Walters, M. Merrick, J. Chen, and M. Stevens, National Intimate Partner and Sexual Violence Survey: 2010 Summary Report (Center for Disease and Control, 2011), https:// www.cdc.gov/violenceprevention/pdf/2015data-brief508 .pdf.

[50] Sexual Harassment of Women: Climate, Culture, and Consequences in Academic Sciences, Engineering, and Medicine, National Academies of Sciences, Engineering, and Medicine (2018), https://umaine.edu/risingtide/ wp-content/uploads/sites/239/2019/04/Sexual-Harassmentof-Women-2018-NAS-Report.pdf.

[51] M. Ong, Body projects of young women of color in physics: Intersections of gender, race, and science, Social problems 52, 593 (2005).

[52] N. W. L. Center, The wage gap: The who, how, why, and what to do (National Women's Law Center, 2020), https:// nwlc.org/wp-content/uploads/2019/09/Wage-Gap-Whohow.pdf.

[53] R. Thomas, M. Cooper, and G. Cardazone, Women in the Workplace 2020 (McKinsey and Company, 2020), http:// hdl.voced.edu.au/10707/558719.

[54] J. Frye, On the Frontlines at Work and at Home: The Disproportionate Economic Effects of the Coronavirus Pandemic on Women of Color, Center of American Progress. Available Online https://www.americanprogress .org/article/frontlines-work-home/ (Accessed 15 May 2020) (2020).

[55] L. M. Aycock, Z. Hazari, E. Brewe, K. B. H. Clancy, T. Hodapp, and R. M. Goertzen, Sexual harassment reported by undergraduate female physicists, Phys. Rev. Phys. Educ. Res. 15, 010121 (2019).

[56] K. B. H. Clancy, R. G. Nelson, J. N. Rutherford, and K. Hinde, Survey of academic field experiences (SAFE): Trainees report harassment and assault, PLoS One 9, e102172 (2014).

[57] T. A. I. P. N. T. F. to Elavate African American Representation in Undergraduate Physics, and Astronomy, The Time Is Now: Systemic Changes to Increase African Americans with Bachelor's in Physics, and Astronomy, Am. Inst. Phys. (2020), https://www.aip.org/sites/default/ files/aipcorp/files/teamup-full-report.pdf.

[58] D. K. Ginther, W. T. Schaffer, J. Schnell, B. Masimore, F. Liu, L. L. Haak, and R. Kington, Race, ethnicity, NIH research awards, Science 333, 1015 (2011).

[59] M. Helmer, M. Schottdorf, A. Neef, and D. Battaglia, Gender bias in scholarly peer review, eLife 6, e21718 (2017).
[60] N. Caplar, S. Tacchella, and S. Birrer, Quantitative evaluation of gender bias in astronomical publications from citation counts, Nat. Astron. 1, 1 (2017).

[61] K. Crenshaw, N. Gotanda, G. Peller, and K. Thomas, Critical race theory, Key Writings That Form. Movement New York 276 (1995).

[62] E. Taylor, D. Gillborn, and G. Ladson-Billings, Foundations of Critical Race Theory in Education (Routledge, London, 2009).

[63] C. L. Ford and C. O. Airhihenbuwa, Critical race theory, race equity, and public health: Toward antiracism praxis, Am. J. Public Health 100, S30 (2010).

[64] T. J. Yosso and D. G. Solórzano, Conceptualizing a critical race theory in sociology, in Blackwell Companion Soc. Inequalities, edited by M. Romero and E. Margolis (Wiley, New York, 2005), p. 117-146, 10.1002/ 9780470996973.ch7.

[65] R. Delgado and J. Stefancic, Critical Race Theory: An Introduction, Vol. 20 (New York University Press, New York, 2017).

[66] A. Martinez, Critical race theory: Its origins, history, and importance to the discourses and rhetorics of race, Fram. Lit. Stud. 27, 9 (2014), https://experts.syr.edu/en/ publications/critical-race-theory-its-origins-history-andimportance-to-the-di.

[67] F. Valdes and S. Cho, Critical race materialism: Theorizing justice in the wake of global neoliberalism, CoNN. L. Rev. 43, 1513 (2010), https://heinonline.org/HOL/ LandingPage handle $=$ hein.journals/conlr43\&div=54\&id= \&page $=$.

[68] S. G. Harding, The Feminist Standpoint Theory Reader: Intellectual and Political Controversies (Psychology Press, London, 2004).

[69] M. Lynn and A. D. Dixson, Handbook of Critical Race Theory in Education, (Routledge, Abingdon, 2013), https:// www.routledge.com/Handbook-of-Critical-Race-Theoryin-Education/Lynn-Dixson/p/book/9781138491724.

[70] B. D. Jones, Critical race theory: New strategies for civil rights in the new millenium, Harv. BlackLetter L. J. 18, 1 (2002), https://heinonline.org/HOL/LandingPage?handle= hein.journals/hblj18\&div=4\&id=\&page $=$.

[71] D. W. Carbado and D. Roithmayr, Critical race theory meets social science, Annu. Rev. Law Soc. Sci. 10, 149 (2014).

[72] G. C. Loury and G. C. Loury, The Anatomy of Racial Inequality (Harvard University Press, Cambridge, MA, 2009).

[73] D. Harper, Etymology of Race, in Online Etymology Dictionary, https://www.etymonline.com/word/race.

[74] R. Dunbar-Ortiz, Not "A Nation of Immigrants": Settler Colonialism, White Supremacy, and a History of Erasure and Exclusion (Beacon Press, Boston, MA, 2021).

[75] L. V. Tischauser, Jim Crow Laws (ABC-CLIO, Greenwood, 2012), Vol. 1.

[76] C. J. E. Warren, Brown v. Board of Education, United States Reports 347, 483 (1954), https://www.loc.gov/ item/usrep347483/.

[77] J. D. Davis, The Supreme Court and Washington v. Davis-A Rationale for Racism, NC Cent. LJ 8, 87 
(1976), https://heinonline.org/HOL/LandingPage?handle= hein.journals/ncclj8\&div=10\&id=\&page $=$.

[78] R. E. Knowlton, Regents of the University of California v. Bakke, Ark. L. Rev. 32, 499 (1978), https://heinonline.org/ HOL/LandingPage?handle=hein.journals/arklr32\&div=34 \&id $=\&$ page $=$.

[79] K. Brown and D. D. Jackson, The History and Conceptual Elements of Critical Race Theory, Handbook of Critical Race Theory in Education (Routledge, London, 2013), pp. 29-42.

[80] A.D. Freeman, Legitimizing racial discrimination through antidiscrimination law: A critical review of supreme court doctrine, Minn. L. Rev. 62, 1049 (1978), https://heinonline.org/HOL/LandingPage?handle=hein .journals $/$ mnlr62\&div $=40 \&$ id $=$ page $=$.

[81] C. R. Lawrence, The id, the ego, and equal protection: Reckoning with unconscious racism, Stanford Law Rev. 39, 317 (1987).

[82] D. Bell, The Derrick Bell Reader, Vol. 75 (NYU Press, New York, 2005).

[83] K. Crenshaw, Mapping the margins: Intersectionality, identity politics, and violence against women of color, Stan. L. Rev. 43, 1241 (1990), https://heinonline.org/ HOL/LandingPage?handle=hein.journals/stflr43\&div=52 \&id $=\&$ page $=$.

[84] D. A. Bell Jr., Brown v. Board of Education and the interest-convergence dilemma, Harvard Law Rev. 93, 518 (1979), https://www.jstor.org/stable/1340546.

[85] W. M. Carter Jr., Thirteenth amendment, interest convergence, and the badges and incidents of slavery, Md. L. Rev. 71, 21 (2011), https://heinonline.org/HOL/Landing Page?handle=hein.journals $/ \mathrm{mllr} 71 \& \mathrm{div}=6 \& \mathrm{id}=\&$ page $=$.

[86] D. Bell, Faces at the Bottom of the Well: The Permanence of Racism (Hachette United Kingdom, 2018).

[87] T.-N. Coates, Between the World and Me (Text Publishing, Spiegel \& Grau, 2015).

[88] S. K. S. Shannon, C. Uggen, J. Schnittker, M. Thompson, S. Wakefield, and M. Massoglia, The growth, scope, and spatial distribution of people with felony records in the United States, 1948-2010, Demography 54, 1795 (2017).

[89] L. D. Bobo, Racism in Trump's America: Reflections on culture, sociology, and the 2016 US presidential election, Br. J. Sociol. Educ. 68, S85 (2017).

[90] E. Brondolo, L. C. Gallo, and H. F. Myers, Race, racism and health: Disparities, mechanisms, and interventions, Journal of behavioral medicine 32, 1 (2009).

[91] D. Gillborn, Racism and Education: Coincidence or Conspiracy? (Routledge, London, 2008).

[92] D. W. Sue, C. M. Capodilupo, G. C. Torino, J. M. Bucceri, A. M. B. Holder, K. L. Nadal, and M. Esquilin, Racial microaggressions in everyday life: Implications for clinical practice, Am. Psychol. 62, 271 (2007).

[93] D. Solorzano, M. Ceja, and T. Yosso, Critical race theory, racial microaggressions, and campus racial climate: The experiences of African American college students, J. Negro Educ. 69, 60 (2000), https://www.jstor.org/ stable/2696265.

[94] M. J. Lee, J. D. Collins, S. A. Harwood, R. Mendenhall, and M. B. Huntt, "If you aren't white, asian or indian, you aren't an engineer": Racial microaggressions in STEM education, Int. J. STEM Educ. 7, 48 (2020).

[95] M. L. Miles, A. J. Brockman, and D. E. Naphan-Kingery, Invalidated identities: The disconfirming effects of racial microaggressions on Black doctoral students in STEM, J. Res. Sci. Teach. 57, 1608 (2020).

[96] L. D. B. Baber, Considering the interest-convergence dilemma in STEM education, Rev. High. Educ. 38, 251 (2015).

[97] G. Ladson-Billings, Foundations to critical race theory in education, Routledge Int. Handb. Crit. Educ. 110 (2009), https://philpapers.org/rec/TAYFOC.

[98] F. Dikötter, Race culture: Recent perspectives on the history of eugenics, Am. Hist. Rev. 103, 467 (1998).

[99] A. Smedley and B. D. Smedley, Race as biology is fiction, racism as a social problem is real: Anthropological and historical perspectives on the social construction of race, Am. Psychol. 60, 16 (2005).

[100] H. Blumer, Race prejudice as a sense of group position, Pac. Sociol. Rev. 1, 3 (1958).

[101] D. D. Bruce, WEB Du Bois and the idea of double consciousness, Am. Lit. 64, 299 (1992).

[102] E. Alsultany, Arabs and Muslims in the media after 9/11: Representational strategies for a "Postrace" era, American Indian quarterly 65, 161 (2013).

[103] D. Domke, K. McCoy, and M. Torres, News media, racial perceptions, and political cognition, Communic. Res. 26, 570 (1999).

[104] F. Hobbs and N. Stoops, Demographic Trends in the 20th Century, Vol. 4 (US Census Bureau, Washington, DC, 2002).

[105] M. T. Bennett, The Immigration and Nationality (McCarran-Walter) Act of 1952, as amended to 1965, Ann. Am. Acad. Pol. Soc. Sci. 367, 127 (1966).

[106] S. A. Annamma, DisCrit: Disability Studies and Critical Race Theory in Education (Teachers College Press, New York, 2016).

[107] D. D. Bernal, Critical race theory, Latino critical theory, and critical raced-gendered epistemologies: Recognizing students of color as holders and creators of knowledge, Qual. Inq. 8, 105 (2002).

[108] A. Liu, Critical race theory, Asian Americans, and higher education: A review of research, Interact. UCLA J. Educ. Inf. Stud. 5 (2009).

[109] B. M. J. Brayboy, Toward a tribal critical race theory in education, Urban Rev. 37, 425 (2005).

[110] C. Andersen, Critical indigenous studies: From difference to density, Cult. Stud. Rev. 15, 80 (2009).

[111] J. Wallis, America's Original Sin: Racism, White Privilege, and the Bridge to a New America (Brazos Press, Grand Rapids, Michigan, 2016).

[112] P. McIntosh, White privilege and male privilege, in Privilege (Routledge, 2018), pp. 28-40, https://www .taylorfrancis.com/chapters/edit/10.4324/97804294948026/white-privilege-male-privilege-peggy-mcintosh.

[113] D. G. Solórzano and T. J. Yosso, Critical race methodology: Counter-storytelling as an analytical framework for education research, Qual. Inq. 8, 23 (2002). 
[114] K. Mitchell, Race, difference, meritocracy, and English: Majoritarian stories in the education of secondary multilingual learners, Race Ethn. Educ. 16, 339 (2013).

[115] L. Hunn, T. C. Guy, and E. Manglitz, Who can speak for whom? Using counterstorytelling to challenge racial hegemony, in Annual Conference of the Adult Education Research Conference, University of Minnesota, Minneapolis (2006), pp. 244-250, https://newprairiepress.org/ aerc/2006/papers/32.

[116] J. J. Pyle, Race, Equality and the Rule of Law: Critical Race Theory's Attack on the Promises of Liberalism, BCL Rev. 40, 787 (1998), https://heinonline.org/HOL/ LandingPage?handle=hein.journals/bclr40\&div=33\&id= \&page $=$.

[117] A. P. Carnevale, M. Fasules, M. Quinn, and K. Peltier Campbell, Born to win, schooled to lose: Why equally talented students don't get equal chances to be all they can be (2019), https://eric.ed.gov/?id=ED599947.

[118] J. Littler, Meritocracy as plutocracy: The marketising of 'equality' under neoliberalism, New Form 80, 52 (2013).

[119] E. D. Knowles and B. S. Lowery, Meritocracy, self-concerns, and whites' denial of racial inequity, Self Identity 11, 202 (2012).

[120] P. L. Carter and K. G. Welner, Closing the Opportunity Gap: What America Must Do to Give Every Child an Even Chance (Oxford University Press, New York, 2013).

[121] G. J. Duncan and R. J. Murnane, Whither Opportunity?: Rising Inequality, Schools, and Children's Life Chances (Russell Sage Foundation, New York, 2011).

[122] G. Ladson-Billings, From the achievement gap to the education debt: Understanding achievement in US schools, Educ. Res. 35, 3 (2006).

[123] J. Wald and D. J. Losen, Out of sight: The journey through the school-to-prison pipeline, Invis. Child. Soc. Its Sch. 3, 23 (2007), https://www.taylorfrancis.com/ chapters/edit/10.4324/9781315672823-9/sight-journeyschool-prison-pipeline-pipeline\%E2\%80\%94johannawald-daniel-losen.

[124] R. J. Skiba, M. I. Arredondo, and M. K. Rausch, New and Developing Research on Disparities In Discipline (Bloom. Equity Proj., Indiana University, Bloomington, IN, 2014).

[125] R. Rothstein, For public schools, segregation then, segregation since, Econ. Policy Inst. (2013), https:// www.epi.org/publication/unfinished-march-public-schoolsegregation/.

[126] J. H. Franklin and E. B. Higginbotham, From Slavery to Freedom: A History of African Americans, in National Tax Association Proceedings (2010), Vol. 103, pp. 112-118, https://www.jstor.org/stable/prancotamamnta.103.112.

[127] R. Chetty and J. N. Friedman, Does local tax financing of public schools perpetuate inequality?, National Tax Association Proc. 103, 112 (2011).

[128] F. I. Stevens, Opportunity to Learn: Issues of Equity for Poor and Minority Students (National Center for Education Statistics, Washington, DC, 1993).

[129] R. J. Skiba, R. S. Michael, A. C. Nardo, and R. L. Peterson, The color of discipline: Sources of racial and gender disproportionality in school punishment, Urban Rev. 34, 317 (2002).
[130] National Center for Education Statistics, Women, Minorities, and Persons with Disabilities in Science and Engineering: 2021, Special Report (National Science Foundation, Washington, DC, 2021).

[131] H. R. Milner IV, Critical race theory and interest convergence as analytic tools in teacher education policies and practices, J. Teach. Educ. 59, 332 (2008).

[132] G. J. Ladson-Billings, Chapter 7: Preparing teachers for diverse student populations: A critical race theory perspective, Rev. Res. Educ. 24, 211 (1999).

[133] D. L. McCoy and D. J. Rodricks, Critical Race Theory in Higher Education: 20 Years of Theoretical and Research Innovations: ASHE Higher Education Report, Volume 41, Number 3 (John Wiley \& Sons, New York, 2015).

[134] T. Yosso, W. Smith, M. Ceja, and D. Solórzano, Critical race theory, racial microaggressions, and campus racial climate for latina/o undergraduates, Harv. Educ. Rev. 79, 659 (2009).

[135] S. A. Harwood, M. B. Huntt, R. Mendenhall, and J. A. Lewis, Racial microaggressions in the residence halls: Experiences of students of color at a predominantly white university, J. Diversity Higher Educ. 5, 159 (2012).

[136] C. T. Pittman, Racial microaggressions: The narratives of African American faculty at a predominantly white university, J. Negro Educ. 81, 82 (2012).

[137] D. G. Solórzano, Critical race theory, race and gender microaggressions, and the experience of Chicana and Chicano scholars, Int. J. Qual. Stud. Educ. 11, 121 (1998).

[138] D. R. Johnson, Campus racial climate perceptions and overall sense of belonging among racially diverse women in STEM majors, J. Coll. Student Dev. 53, 336 (2012).

[139] E. N. Winkler, Children are not colorblind, Pace 3, 1 (2009), http://health.umt.edu/ccfwd/resource_library/ resources/Crucial\%20Conversations/Children_Are_Not_ Colorblind_How_Young_Ch-1.pdf.

[140] P. H. Collins, Black Feminist Thought: Knowledge, Consciousness, and the Politics of Empowerment (Routledge, London, 2002).

[141] S. Harding, Whose Science? Whose Knowledge?: Thinking from Women's Lives (Cornell University Press, Ithaca, NY, 1991).

[142] E. Anderson, Feminist epistemology and philosophy of science, The Stanford Encyclopedia of Philosophy (Spring 2020 Edition), https://plato.stanford.edu/archives/ spr2020/entries/feminism-epistemology.

[143] K. Marx and F. Engels, The Communist Manifesto (1848), Translated by Samuel Moore (Penguin, London, 1967).

[144] H. Rose, Hand, brain, and heart: A feminist epistemology for the natural sciences, Signs J. Women Cult. Soc. 9, 73 (1983).

[145] D. Haraway, Situated knowledges: The science question in feminism and the privilege of partial perspective, Fem. Stud. 14, 575 (1988), https://www.jstor.org/stable/ 3178066.

[146] N. C. Hartsock, Money, Sex, and Power: Toward a Feminist Historical Materialism (Longman, New York, 1983).

[147] M. Lederman and I. Bartsch, The Gender and Science Reader (Psychology Press, London, 2001). 
[148] D. J. Haraway, Primate Visions: Gender, Race, and Nature in the World of Modern Science (Psychology Press, London, 1989).

[149] D. Haraway, Animal sociology and a natural economy of the body politic, Part I: A political physiology of dominance, Signs J. Women Cult. Soc. 4, 21 (1978).

[150] L. Schiebinger, Has feminism changed science?, Figurationen 24, 50 (1999), https://www.journals.uchicago .edu/doi/abs/10.1086/495540?journalCode=signs.

[151] J. Des Jardins, The Madame Curie Complex: The Hidden History of Women in Science (The Feminist Press at CUNY, New York, 2010).

[152] L. Schiebinger, Who really wore the pants?, Nat. Med. 10, 669 (2004).

[153] J.C. Bennett, Inclusion of women in clinical trialspolicies for population subgroups, New Engl. J. Med. 329, 288 (1993).

[154] D. D. Smith, J. L. Pippen, A. A. Adesomo, K. M. Rood, M. B. Landon, and M. M. Costantine, Exclusion of pregnant women from clinical trials during the coronavirus disease 2019 pandemic: A review of international registries, Am. J. Perinatol. 37, 792 (2020).

[155] C. Vitale, M. Fini, I. Spoletini, M. Lainscak, P. Seferovic, and G. M. C. Rosano, Under-representation of elderly and women in clinical trials, International Journal of Cardiology 232, 216 (2017).

[156] S. Harding, Standpoint theories: Productively controversial, Hypatia 24, 192 (2009), https://www.cambridge .org/core/journals/hypatia/article/abs/standpoint-theoriesproductively-controversial/3AECE924A2BFC03CFDC9 CB27BAC75BCE.

[157] K. Weiler, Freire and a feminist pedagogy of difference, Harv. Educ. Rev. 61, 449 (1991).

[158] P. H. Collins, Learning from the outsider within: The sociological significance of black feminist thought, Social problems 33, s14 (1986).

[159] S. Harding (Villanova University), Sandra Harding: On Standpoint Theory's History and Controversial Reception, https://www.youtube.com/watch?v=tdsxuRpM3hI.

[160] A. L. Traxler, X. C. Cid, J. Blue, and R. Barthelemy, Enriching gender in physics education research: A binary past and a complex future, Phys. Rev. Phys. Educ. Res. 12, 020114 (2016).

[161] H. Iddy, Indigenous standpoint theory: Ethical principles and practices for studying Sukuma people in Tanzania, Aust. J. Indig. Educ. 50, 385 (2021).

[162] N. Ruck, A. Rutherford, M. Brunner, and K. Hametner, Scientists as (not) knowing subjects: Unpacking standpoint theory and epistemological ignorance from a psychological perspective, Psychological Studies of Science and Technology (Springer, New York, 2019), pp. 127-148.

[163] C. Etengoff, Repositioning cultural competency with clinical doctoral students: Unpacking intersectionality, standpoint theory, and multiple minority stress/resilience, Women \& Ther. 43, 348 (2020).

[164] S. Truth and A. P. Kennedy, Ain't I a Woman? (1851).

[165] K.-Y. Taylor, How We Get Free: Black Feminism and the Combahee River Collective (Haymarket Books, 2017).
[166] Z. Hazari, G. Sonnert, P. M. Sadler, and M.-C. Shanahan, Connecting high school physics experiences, outcome expectations, physics identity, and physics career choice: A gender study, J. Res. Sci. Teach. 47, 978 (2010).

[167] Z. Hazari, P. M. Sadler, and G. Sonnert, The science identity of college students: Exploring the intersection of gender, race, and ethnicity, J. Coll. Sci. Teach. 42, 82 (2013), https://www.jstor.org/stable/43631586.

[168] S. Hyater-Adams, C. Fracchiolla, N. Finkelstein, and K. Hinko, Critical look at physics identity: An operationalized framework for examining race and physics identity, Phys. Rev. Phys. Educ. Res. 14, 010132 (2018).

[169] S. Herrera, I. A. Mohamed, and A. R. Daane, Physics from an underrepresented lens: What I wish others knew, Phys. Teach. 58, 294 (2020).

[170] R. E. Scherr, M. A. Lopez, and M. Rosario-Franco, Isolation and connectedness among Black and Latinx physics graduate students, Phys. Rev. Phys. Educ. Res. 16, 020132 (2020).

[171] A. A. Eaton, J. F. Saunders, R. K. Jacobson, and K. West, How gender and race stereotypes impact the advancement of scholars in STEM: Professors' biased evaluations of physics and biology post-doctoral candidates, Sex Roles 82, 127 (2020).

[172] K. Rosa, Race, gender, and sexual minorities in physics: Hashtag activism in Brazil, in Upgrading Physics Education to Meet the Needs of Society (Springer, New York, 2019), pp. 221-238.

[173] A. Johnson, M. Ong, L. T. Ko, J. Smith, and A. Hodari, Common challenges faced by women of color in physics, and actions faculty can take to minimize those challenges, Phys. Teach. 55, 356 (2017).

[174] D. Dickens, M. Jones, and N. Hall, Being a token Black female faculty member in physics: Exploring research on gendered racism, identity shifting as a coping strategy, and inclusivity in physics, Phys. Teach. 58, 335 (2020).

[175] A. Johnson, R. Young, and E. Mulvey, Where do women of color complete physics degrees?, Phys. Teach. 58, 620 (2020).

[176] C. Prescod-Weinstein, Making Black women scientists under White empiricism: The racialization of epistemology in physics, Signs J. Women Cult. Soc. 45, 421 (2020).

[177] L. T. Ko, R. R. Kachchaf, A. K. Hodari, and M. Ong, Agency of women of color in physics and astronomy: Strategies for persistence and success, J. Women Minorities Sci. Eng. 20, 171 (2014).

[178] B. Van Dusen and J. Nissen, Associations between learning assistants, passing introductory physics, and equity: A quantitative critical race theory investigation, Phys. Rev. Phys. Educ. Res. 16, 010117 (2020).

[179] J. M. Nissen, I. H. M. Horses, and B. Van Dusen, Investigating society's educational debts due to racism and sexism in student attitudes about physics using quantitative critical race theory, Phys. Rev. Phys. Educ. Res. 17, 010116 (2021).

[180] T. Zuberi, Thicker than Blood: How Racial Statistics Lie (University of Minnesota Press, Minneapolis, MN, 2001).

[181] T. Zuberi, E. Bonilla-Silva et al., White Logic, White Methods: Racism and Methodology (Rowman \& Littlefield Publishers, Lanham, Maryland, 2008). 
[182] D. Gillborn, P. Warmington, and S. Demack, QuantCrit: Education, policy,'big data'and principles for a critical race theory of statistics, Race Ethn. Educ. 21, 158 (2018).

[183] L. McCall, The complexity of intersectionality, Signs J. Women Cult. Soc. 30, 1771 (2005).

[184] N. M. Garcia, N. López, V. N. Vélez, and V. N. Velez, QuantCrit: Rectifying quantitative methods through critical race theory, Race Ethn. Educ. 21, 149 (2018).

[185] S. Cho, K. W. Crenshaw, and L. Mccall, Toward a field of intersectionality studies: Theory, applications, and praxis, Signs J. Women Cult. Soc. 38, 785 (2013).

[186] T. Bowell, Feminist standpoint theory, in The Internet Encyclopedia of Philosophy (2011), https://iep.utm.edu/ fem-stan/.

[187] S. D. Museus, R. T. Palmer, R. J. Davis, and D. C. Maramba, Racial and ethnic minority students' success in STEM education., ASHE High. Educ. Rep. 36, 1 (2011).
[188] C. Pewewardy and B. Frey, Surveying the landscape: Perceptions of multicultural support services and racial climate at a predominantly white university, J. Negro Educ. 71, 77 (2002), https://www.jstor.org/stable/ 3211226.

[189] S. Hurtado, The campus racial climate: Contexts of conflict, J. Higher Educ. 63, 539 (1992).

[190] E. Brewe, V. Sawtelle, L. H. Kramer, G. E. O'Brien, I. Rodriguez, P. Pamelá, G. E. O’Brien, I. Rodriguez, and P. Pamelá, Toward equity through participation in modeling instruction in introductory university physics, Phys. Rev. ST Phys. Educ. Res. 6, 010106 (2010).

[191] M. Lorenzo, C. H. Crouch, and E. Mazur, Reducing the gender gap in the physics classroom, Am. J. Phys. 74, 118 (2006).

[192] C. Henderson, M. Dancy, and M. Niewiadomska-Bugaj, Use of research-based instructional strategies in introductory physics: Where do faculty leave the innovationdecision process?, Phys. Rev. ST Phys. Educ. Res. 8, 020104 (2012). 